\title{
PARAMETRIC STUDY AND ANALYSIS OF PRE-STRESSED CONCRETE BOX GIRDER BRIDGE
}

\author{
Rashmi R Koushik ${ }^{1}$, Shilpa Patil ${ }^{2}$, Rakesh $\mathbf{R}^{3}$ \\ ${ }^{1}$ MTech Student, Department of Civil Engineering, Global Academy of Technology, Bengaluru -560098 \\ ${ }^{2}$ Asst. Professor, Department of Civil Engineering, Global Academy of Technology, Bengaluru -560098 \\ ${ }^{3}$ MTech Student, Department of Civil Engineering, Global Academy of Technology, Bengaluru -560098
}

\begin{abstract}
The importance of highway bridges in a modern transportation system aims in providing safety and quality in construction. This paper discusses the Parametric study and Analysis of Prestressed Concrete Box-girder bridge and focuses on the Structural Analysis comparison of Simply Supported, Continuous and Overhang bridges for the same loading conditions to find the most economical cross-section for various spans. A three span bridge model with four lanes is considered. Span length being $30 \mathrm{~m}$, $36 \mathrm{~m}, 45 \mathrm{~m}, 51 \mathrm{~m}, 60 \mathrm{~m}, 66 \mathrm{~m}, 75 \mathrm{~m}, 81 \mathrm{~m}, 90 \mathrm{~m}, 96 \mathrm{~m}, 105 \mathrm{~m}, 111 \mathrm{~m}$ and $120 \mathrm{~m}$ respectively. The live load assigned for the bridge model is IRC Class A Wheeled loading. The Code considered for bridge design is the Indian code (IRC-2000). Analysis is carried out using the computer software CSi Bridge v17.0.
\end{abstract}

Keywords-Box Girder; Pre-stressing; Simply Supported; Continuous; Overhang; Deflection; IRC Class A loading. - ****

\section{INTRODUCTION}

A bridge is that structure built for carrying the road / rail movement or other moving loads. A box girder bridge is either a Structural steel, Pre-stressed concrete, Reinforced concrete or composite section bridge in which the girders are hollow box shape. It is either trapezoidal, circular, square, rectangular or tailor made in cross-section. Pre-stressing is defined as the initiation of compressive force to the concrete to restrain the stresses resulting from an applied load. For longer spans, Pre-stressed box girders are chosen as the depth of the box girder can be reduced remarkably when compared to normal I-girders. When compared to T-beam Girder Bridge, longer spans can be incorporated in a Box girder bridge, thereby resulting in lesser number of piers and also economy. The closed cell within the box girder has higher torsional stiffness and strength than an open section. This is the main basis for choosing a box girder configuration. A Simply Supported bridge has many individual spans and is usually used for adjacent spans of different dimensions or different geometries. Each span is supported with roller/hinges at the ends upon which the loads act. A Continuous bridge is a statically indeterminate structure continuous for two or more intermediate supports. A Overhang bridge has a portion of the deck built additionally over the beams. It consists of a Simply Supported central span. The overhang is provided such that fewer number of beams are incorporated. The dimension of the overhang being $1 / 4$ or $1 / 5$ of the total span. This reduces the bending moment to about $50 \%$ of the moment for a simply supported beam. The main aim of this project is to keep the deflection within the permissible limits for each of the support conditions.
2. MATERIAL PROPERTIES

AND

\section{ALLOWABLE STRESS}

- Material properties:

1) Grade of concrete: $\mathrm{M} 45=45 \mathrm{~N} / \mathrm{mm}^{2}$

2) Young's modulus $(\mathrm{E})=3.35 * 10^{7} \mathrm{kN} / \mathrm{m}^{2}$

3) Poisson's ratio $(v)=0.2$

4) Shear Modulus $(\mathrm{G})=1.39 * 10^{7} \mathrm{kN} / \mathrm{m}^{2}$

5) Coefficient of thermal expansion $(\mathrm{A})=5.5^{*} 10^{-6}$

6) Specific comp. strength of concrete $\left(\mathrm{f}_{\mathrm{c}}{ }^{1}\right)=45 \mathrm{kN} / \mathrm{m}$

- Tendon Properties:

1) Type of pre-stressing - Post tensioning

2) Diameter of the pre-stressing cable: ASTM 0.5

3) Pre-stressing Strand: $13 \mathrm{~mm}(0.5$ "strand)

4) Modulus of Elasticity: Eps $=1.968 * 10^{8} \mathrm{kN} / \mathrm{m}^{2}$

5) Elastic shortening stress: $20684.274 \mathrm{kN} / \mathrm{m}^{2}$

6) Creep stress: $34473.79 \mathrm{kN} / \mathrm{m}^{2}$

7) Shrinkage stress: $48263.31 \mathrm{kN} / \mathrm{m}^{2}$

8) Steel relaxation stress: $34473.79 \mathrm{kN} / \mathrm{m}^{2}$

9) Curvature coefficient: 0.15

10) Wobble coefficient: $6.56 * 10^{-4}$

11) Anchorage Slip: $6.35^{*} 10^{-3}$

12) Coefficient of thermal expansion $(\mathrm{A})=1.17 * 10^{-5}$

13) Minimum yield stress $=F_{y}=1689.9 * 10^{3} \mathrm{KN} / \mathrm{m}^{2}$

14) Minimum tensile stress $=F_{u}=1861.58^{*} 10^{3} \mathrm{KN} / \mathrm{m}^{2}$

15) Total number of tendons: 1

- Rebar properties:

1) Grade of steel: HYSD500 $=500 \mathrm{~N} / \mathrm{mm}^{2}$

2) Young's modulus $(\mathrm{E})=2.00 * 10^{8} \mathrm{kN} / \mathrm{m}^{2}$

3) Poisson's ratio $(v)=0.3$

4) Coefficient of thermal expansion $(\mathrm{A})=1.17 * 10^{-5}$

5) Minimum yield stress $=\mathrm{F}_{\mathrm{y}}=5 * 10^{5} \mathrm{KN} / \mathrm{m}^{2}$

6) Minimum tensile stress $=F_{u}=5.45 * 10^{5} \mathrm{KN} / \mathrm{m}^{2}$ 
- Abutment properties:
1) Abutment depth $=2.3 \mathrm{~m}$
2) Abutment width $=0.5 \mathrm{~m}$
3) Cross section area $=1.15 \mathrm{~m}^{2}$
4) Moment of Inertia about 3 axis $=0.507 \mathrm{~m}^{4}$
5) Moment of Inertia about 2 axis $=0.024 \mathrm{~m}^{4}$
6) Section modulus about 3 axis $=0.4408 \mathrm{~m}^{3}$
7) Section modulus about 2 axis $=0.0958 \mathrm{~m}^{3}$

- Column properties:

1) Circular column diameter $=1.5 \mathrm{~m}$

2) Cross section area $=1.7671 \mathrm{~m}^{2}$

3) Moment of Inertia about 3 axis $=0.2485 \mathrm{~m}^{4}$

4) Moment of Inertia about 2 axis $=0.2485 \mathrm{~m}^{4}$

5) Section modulus about 3 axis $=0.3313 \mathrm{~m}^{3}$

6) Section modulus about 2 axis: $0.3313 \mathrm{~m}^{3}$

- Bent properties:

1) Bent cap depth $=4 \mathrm{~m}$

2) Bent cap width $=2 \mathrm{~m}$

3) Cross section area $=8 \mathrm{~m}^{2}$

4) Moment of Inertia about 3 axis $=10.66 \mathrm{~m}^{4}$

5) Moment of Inertia about 2 axis $=2.66 \mathrm{~m}^{4}$

6) Section modulus about 3 axis $=5.33 \mathrm{~m}^{3}$

7) Section modulus about 2 axis $=2.66 \mathrm{~m}^{3}$

\section{CROSS SECTION SPECIFICATION (As per}

IRC: 18 - 2000)

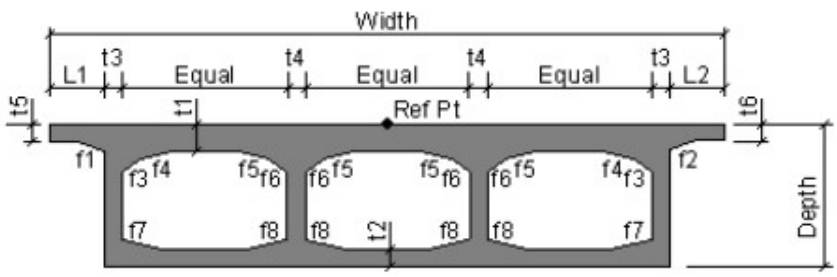

Fig 1.0 - Cross section of the deck

1) Type of structure: Multi-cell PSC Box girder

2) Depth of box girder $=2.3 \mathrm{~m}$

3) Total top width of box girder $=17.2 \mathrm{~m}$

4) Total bottom width of box girder $=14.2 \mathrm{~m}$

5) Thickness of web(t3, t4) $=0.35 \mathrm{~m}$

6) Thickness of bottom slab(t2) $=0.25 \mathrm{~m}$

7) Thickness of top slab(t1) $=0.35 \mathrm{~m}$

8) Diaphragm thickness $=0.3 \mathrm{~m}$

9) Diaphragm depth $=1 \mathrm{~m}$

10) Number of cells $=3$

11) Number of interior girders $=3$

12) Vertical fillet dimension(f1 to $\mathrm{f} 8)=0.15 \mathrm{~m}$

13) Horizontal fillet dimension(f1 to $\mathrm{f} 8$ ) $=0.6 \mathrm{~m}$

14) Left overhang length(L1) $=1.5 \mathrm{~m}$

15) Right overhang length(L2) $=1.5 \mathrm{~m}$

\section{LOADING ON BOX GIRDER}

Dead Loads - It consists of fixed loads, weight of the superstructure, including own weight of the member.

Superimposed Dead Loads - It includes footpaths, earthfills, formwork, ballast, signs, wearing surface, pipes, conduits, water-proofing cables and other externally installed accessories on the structure.

Prestressing force - Varies with respect to the span.

Vehicle Live Loads - The vehicles passing over the bridge are considered. Vehicle live loads are classified as Class 70R, IRC Class AA (tracked and wheeled), IRC Class A and IRC Class B loading. In this project, IRC Class A loading is considered.

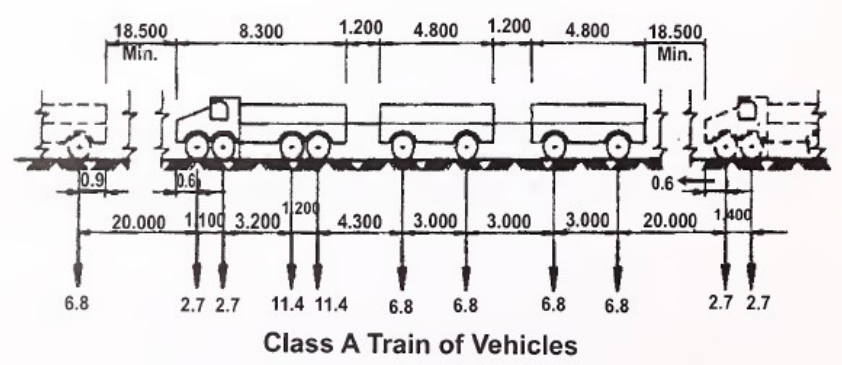

Fig 1.1 - IRC Class A loading
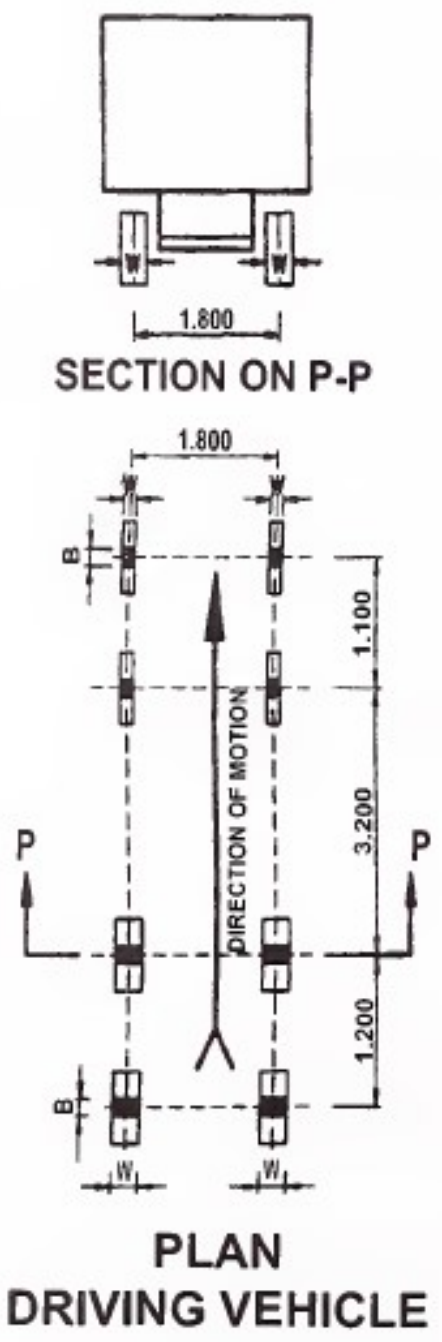

Fig 1.2 - Plan of loading of vehicles 


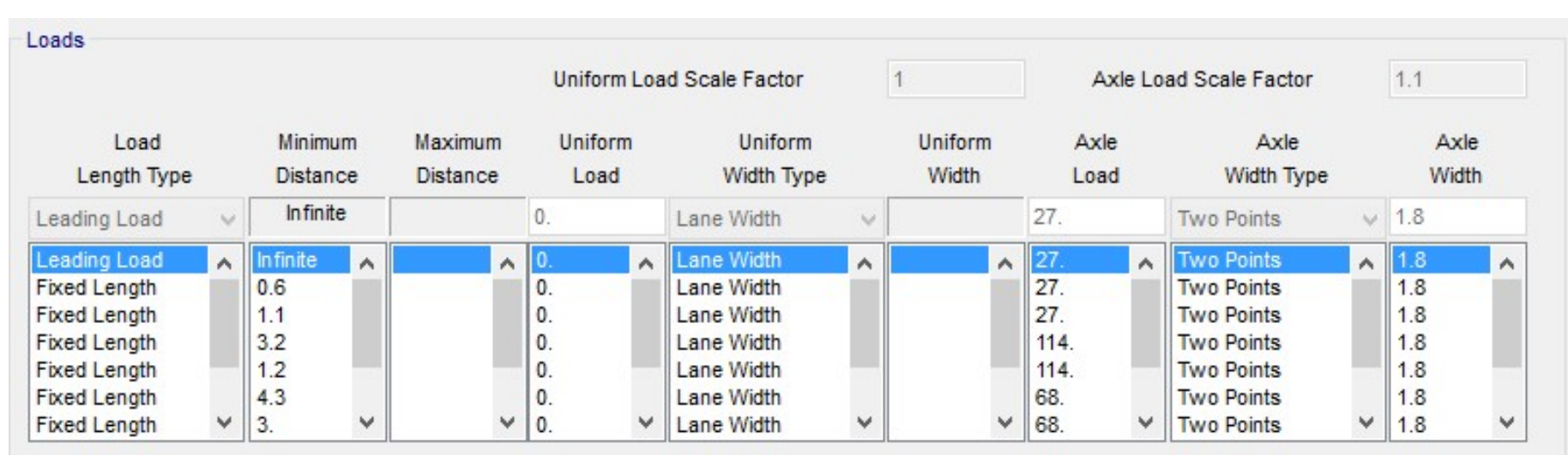

Fig 1.3 - Assigned Live load values using the software

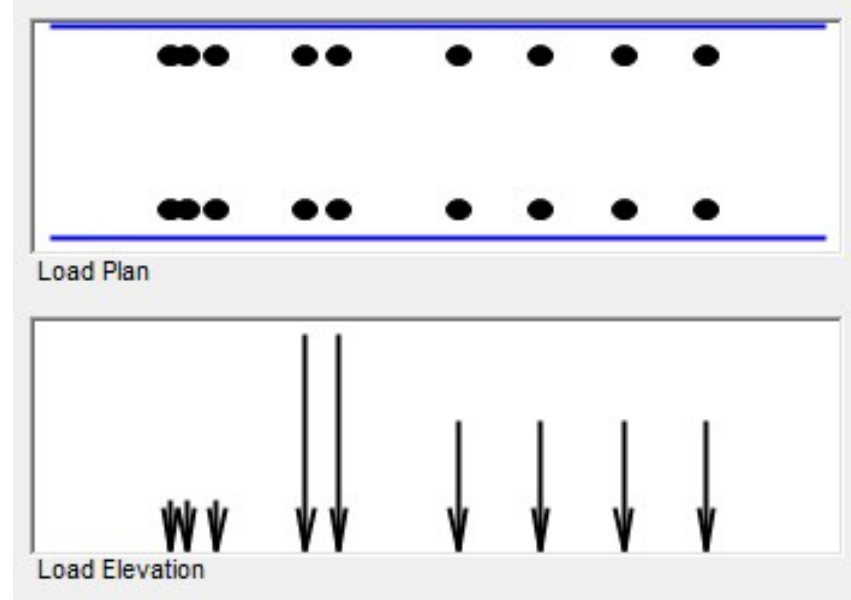

Fig 1.4 - Plan and Elevation of the assigned Live loads

\section{Load Combinations}

Table 1.1 - Load combination

\begin{tabular}{|c|c|c|c|c|}
\hline \multicolumn{4}{|c|}{ Without Pre-stressing force, } & \\
\hline Loads & Dead & $\begin{array}{l}\text { Super- } \\
\text { imposed } \\
\text { Dead }\end{array}$ & Live & \\
\hline Value & 1 & 1 & 1 & \\
\hline \multicolumn{5}{|c|}{ With Pre-stressing force, } \\
\hline Loads & Dead & $\begin{array}{l}\text { Super- } \\
\text { imposed } \\
\text { Dead }\end{array}$ & Live & Prestress \\
\hline Value & 1 & 1 & 1 & 1 \\
\hline
\end{tabular}

\subsection{SPAN - 30m}

\subsubsection{Simply Supported}

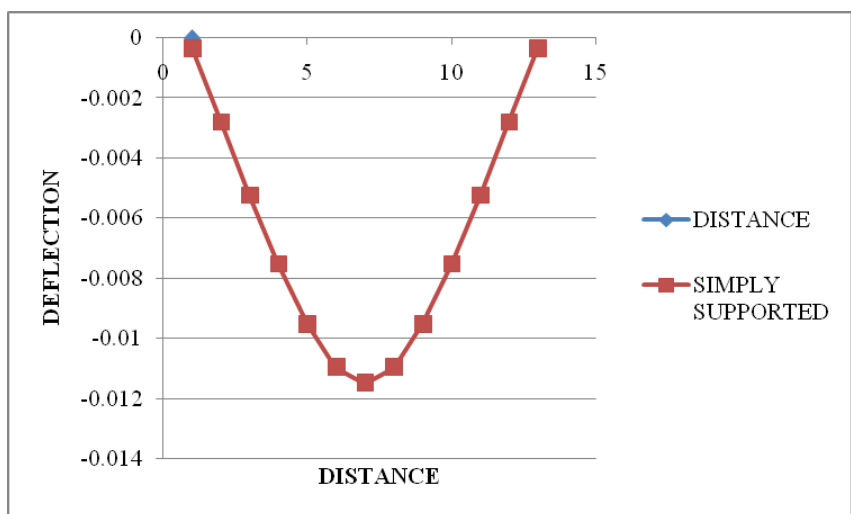

Chart 1.0 - Deflection Vs Distance for Simply supported bridge without Pre-stressing force for $30 \mathrm{~m}$ span.

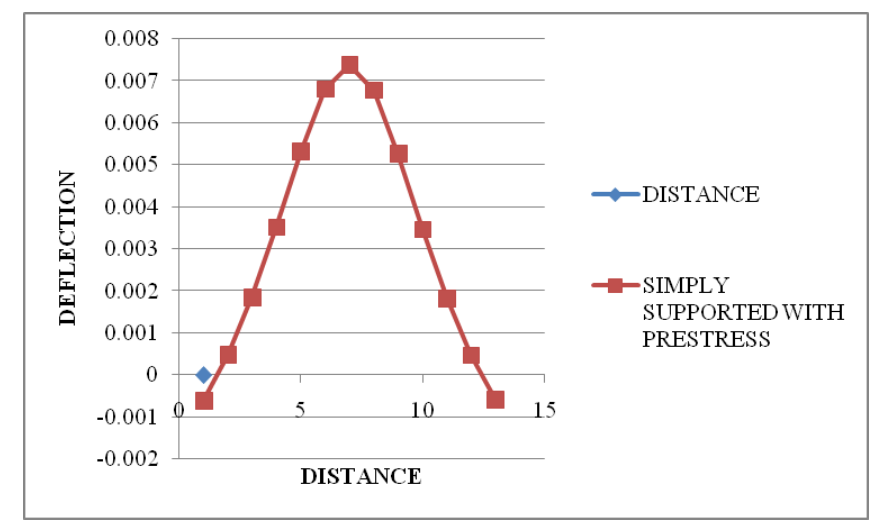

Chart 1.1 - Deflection Vs Distance for Simply supported bridge with Pre-stressing force for $30 \mathrm{~m}$ span.

\section{ANALYSIS}

NOTE: DIMENSIONS IN X AXIS - $\mathrm{m}$

DIMENSIONS IN Y AXIS - $\mathrm{m}$ 


\subsubsection{Continuous}

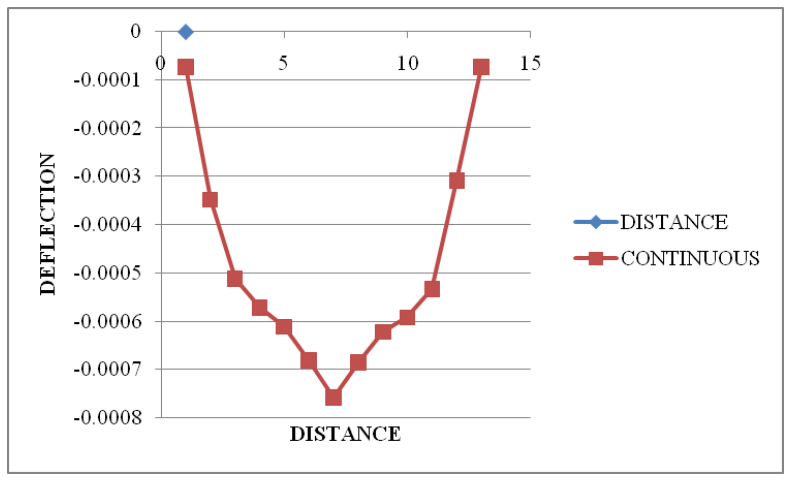

Chart 1.2 -Deflection Vs Distance for Continuous bridge without Pre-stressing force for $30 \mathrm{~m}$ span.

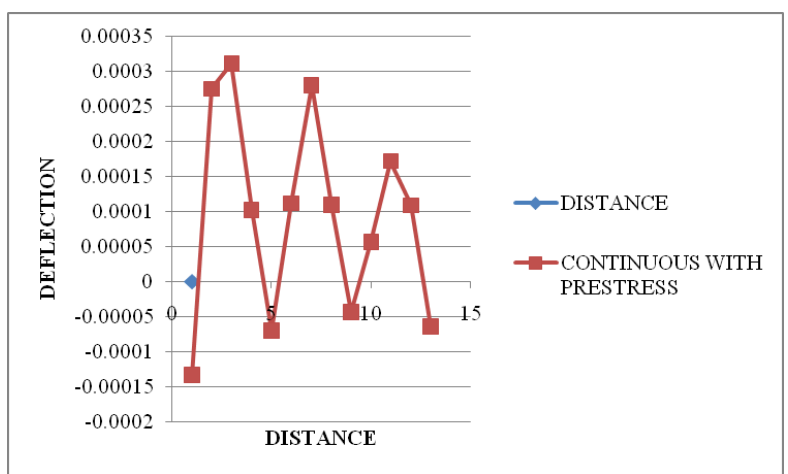

Chart 1.3 - Deflection Vs Distance for Continuous bridge with Pre-stressing force for $30 \mathrm{~m}$ span.

\subsubsection{Overhang}

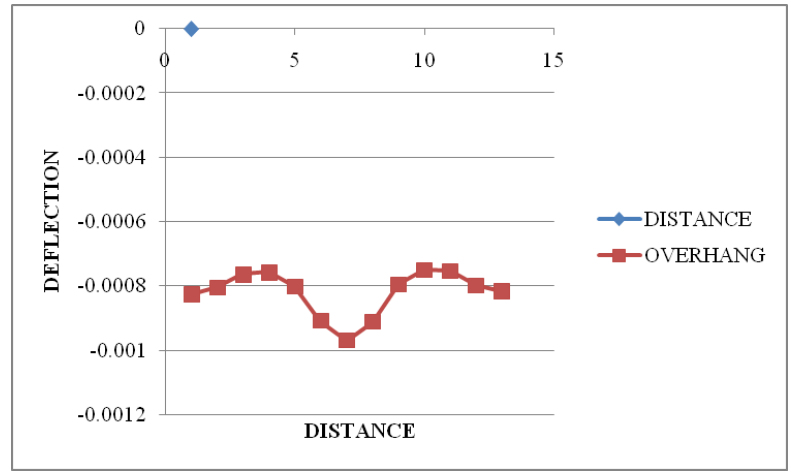

Chart 1.4 - Deflection Vs Distance for Overhang bridge without Pre-stressing force for $30 \mathrm{~m}$ span.

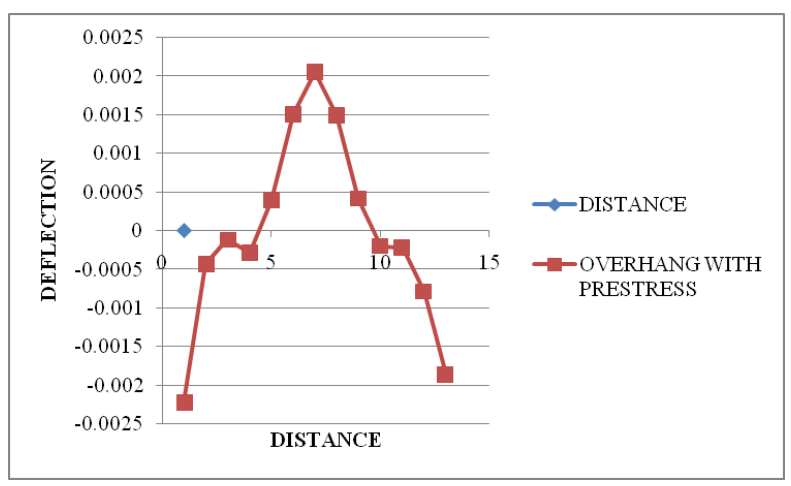

Chart 1.5 - Deflection Vs Distance for Overhang bridge with Pre-stressing force for $30 \mathrm{~m}$ span.
5.2 SPAN - 36m

5.2.1 Simply Supported

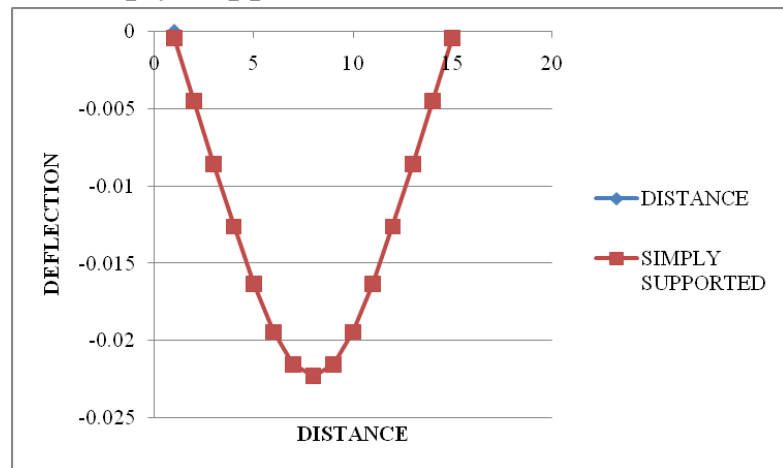

Chart 1.6 - Deflection Vs Distance for Simply supported bridge without Pre-stressing force for $36 \mathrm{~m}$ span.

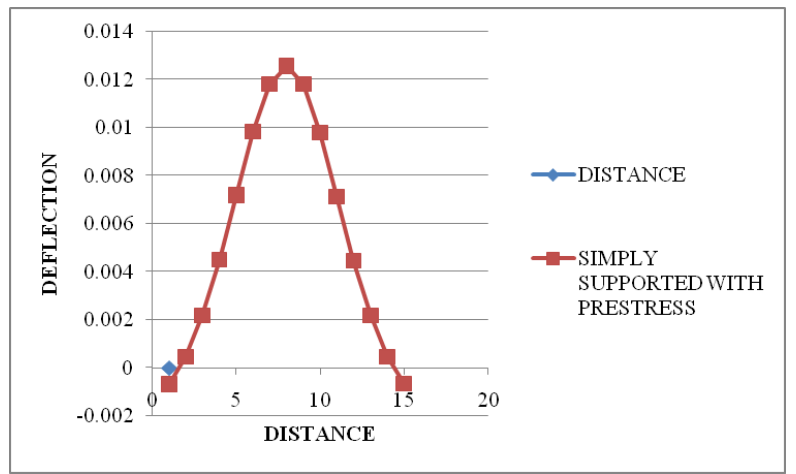

Chart 1.7 - Deflection Vs Distance for Simply supported bridge with Pre-stressing force for $36 \mathrm{~m}$ span.

\subsubsection{Continuous}

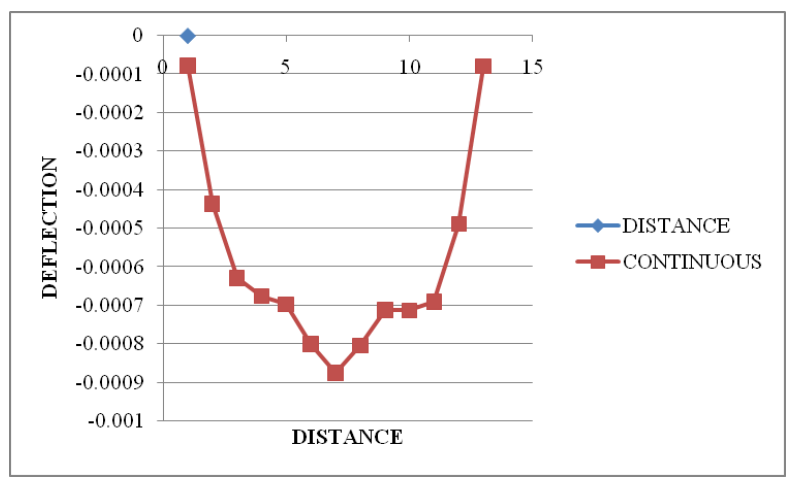

Chart 1.8 - Deflection Vs Distance for Continuous bridge without Pre-stressing force for $36 \mathrm{~m}$ span.

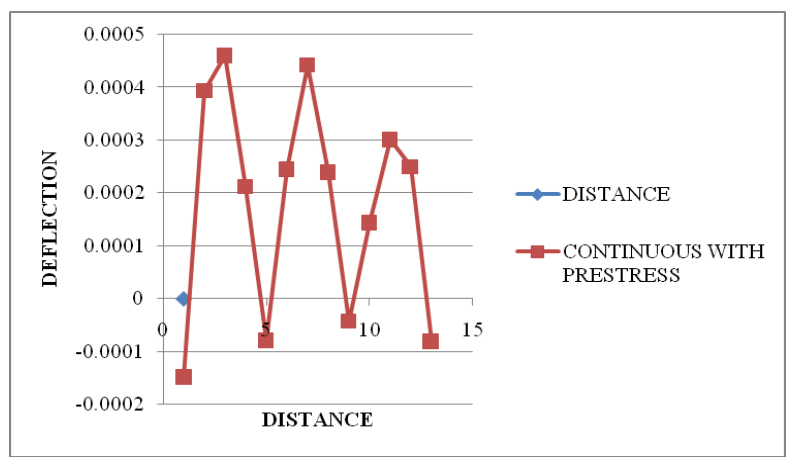

Chart 1.9 - Deflection Vs Distance for Continuous bridge with Pre-stressing force for $36 \mathrm{~m}$ span. 


\subsubsection{Overhang}

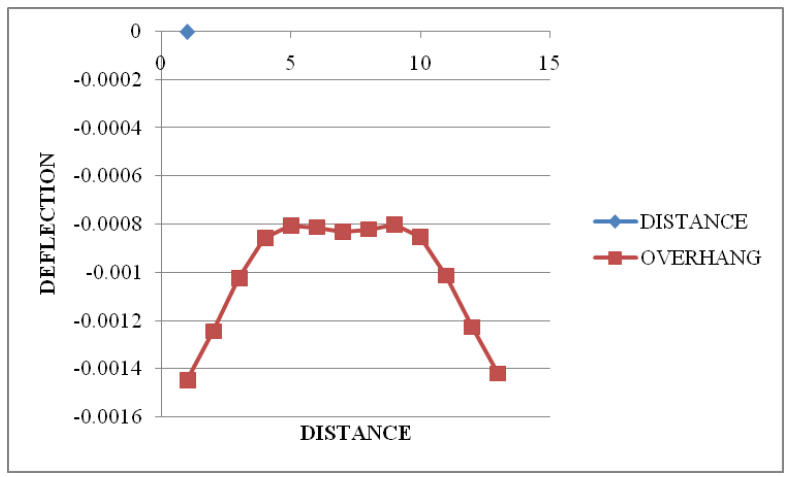

Chart 2.0 - Deflection Vs Distance for Overhang bridge without Pre-stressing force for $36 \mathrm{~m}$ span.

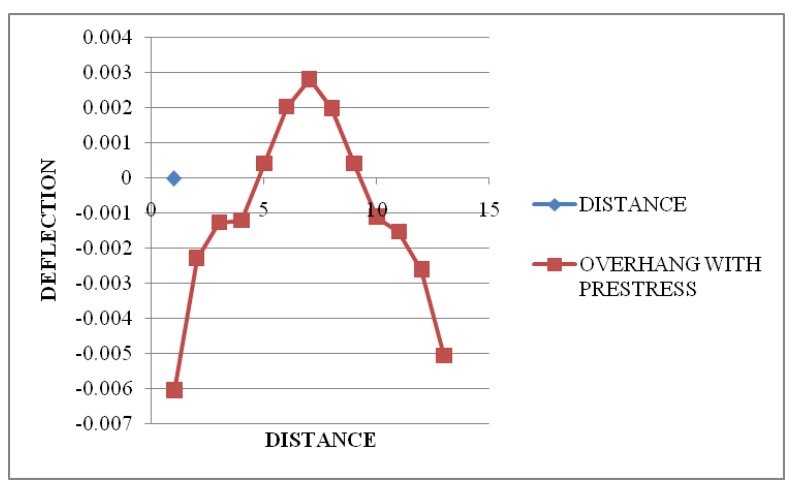

Chart 2.1 - Deflection Vs Distance for Overhang bridge with Pre-stressing force for $36 \mathrm{~m}$ span.

\subsection{SPAN - 45m}

\subsubsection{Simply Supported}

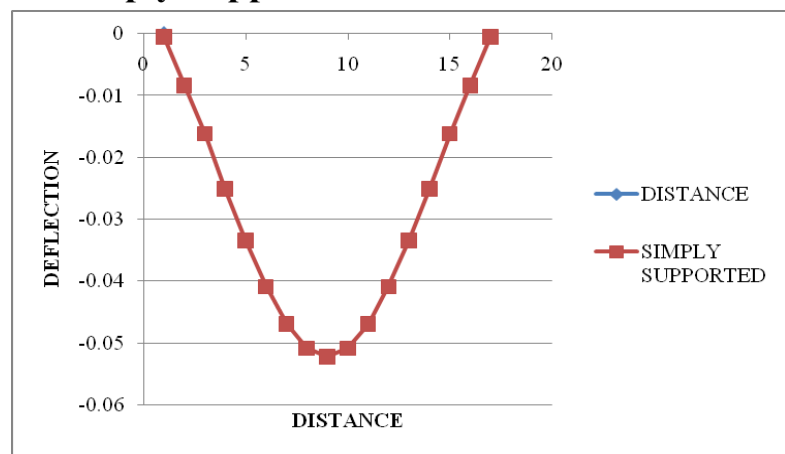

Chart 2.2 - Deflection Vs Distance for Simply supported bridge without Pre-stressing force for $45 \mathrm{~m}$ span.

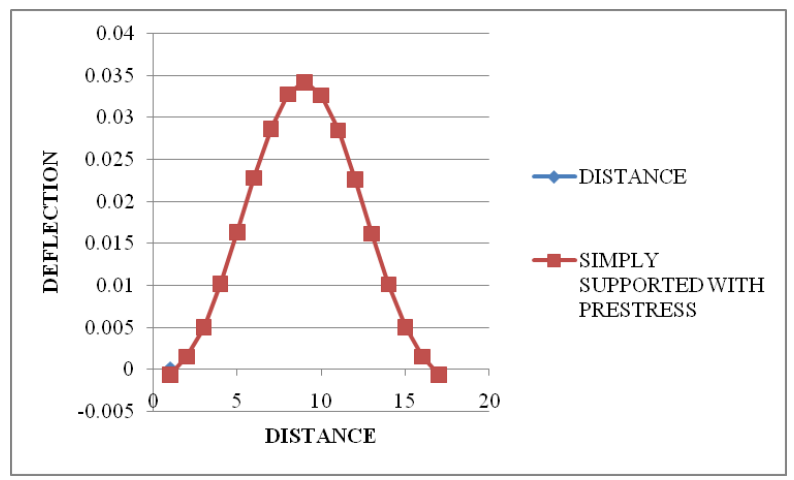

Chart 2.3 - Deflection Vs Distance for Simply supported bridge with Pre-stressing force for $45 \mathrm{~m}$ span.

\subsubsection{Continuous}

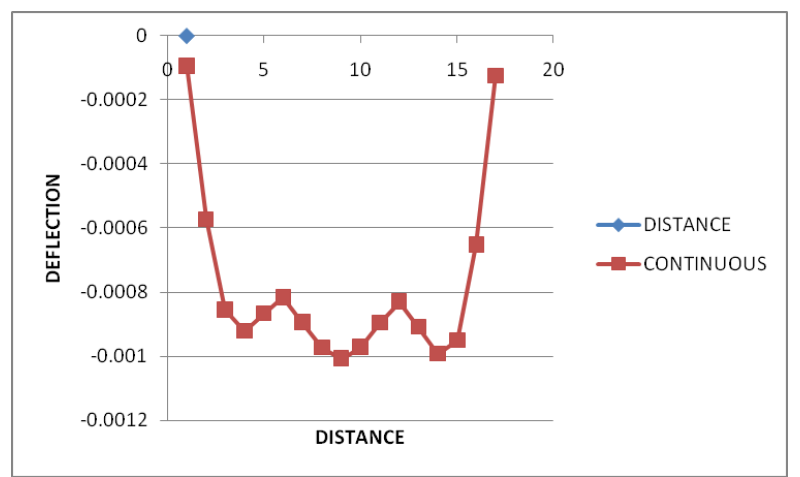

Chart 2.4 - Deflection Vs Distance for Continuous bridge without Pre-stressing force for $45 \mathrm{~m}$ span.

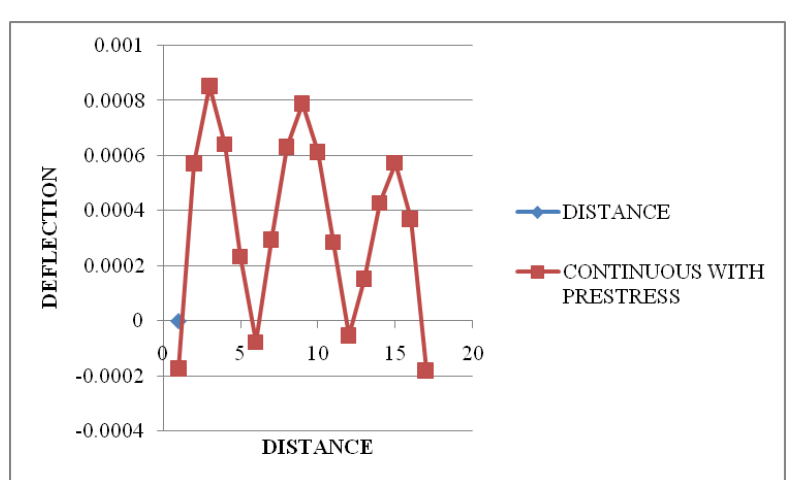

Chart 2.5 - Deflection Vs Distance for Continuous bridge with Pre-stressing force for $45 \mathrm{~m}$ span.

\subsubsection{Overhang}

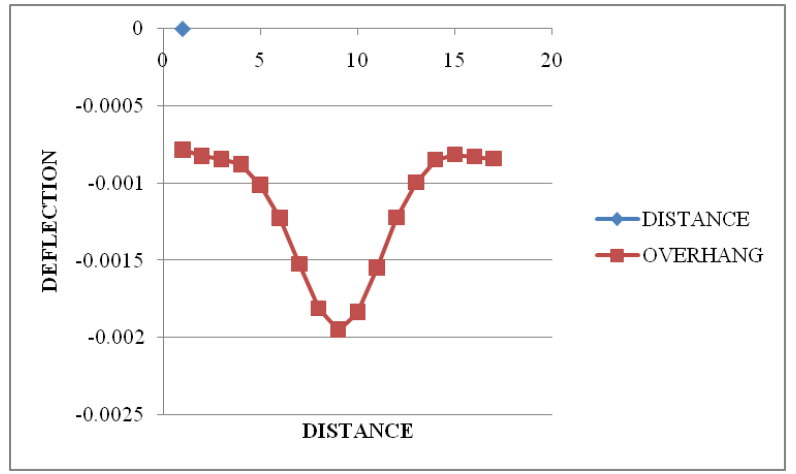

Chart 2.6 - Deflection Vs Distance for Overhang bridge without Pre-stressing force for $45 \mathrm{~m}$ span.

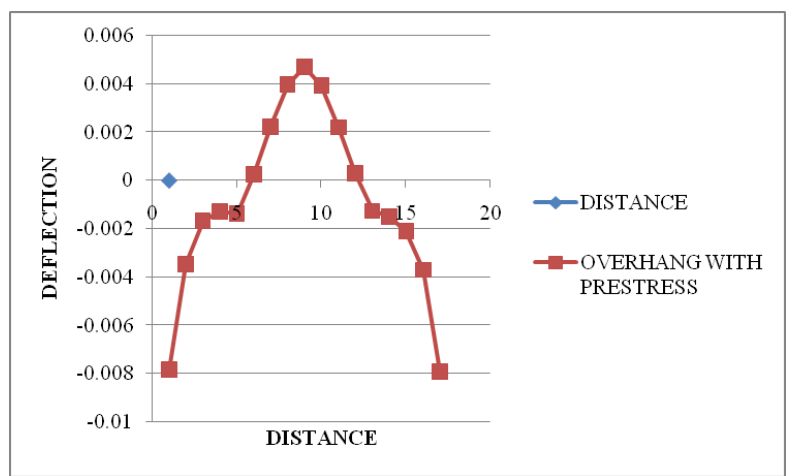

Chart 2.7 - Deflection Vs Distance for Overhang bridge with Pre-stressing force for $45 \mathrm{~m}$ span. 
5.4 SPAN $-51 \mathrm{~m}$

\subsubsection{Simply Supported}

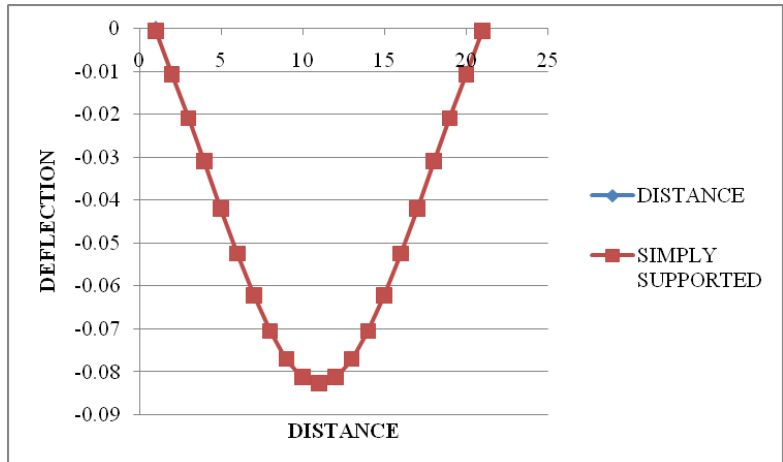

Chart 2.8 - Deflection Vs Distance for Simply supported bridge without Pre-stressing force for $51 \mathrm{~m}$ span.

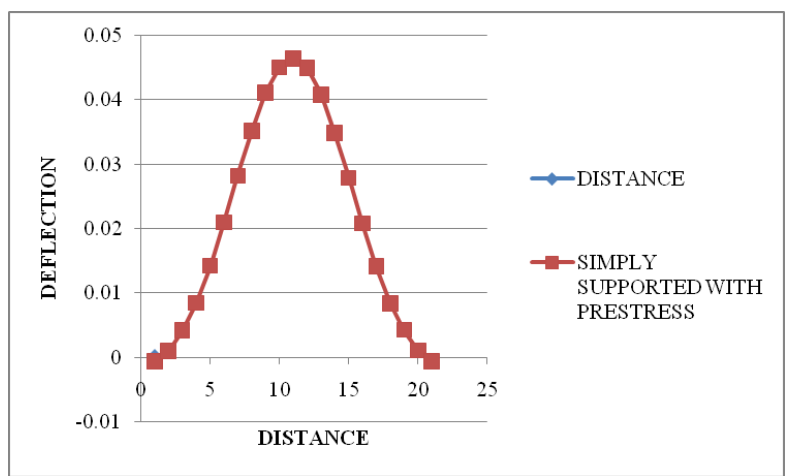

Chart 2.9 - Deflection Vs Distance for Simply supported bridge with Pre-stressing force for $51 \mathrm{~m}$ span.

\subsubsection{Continuous}

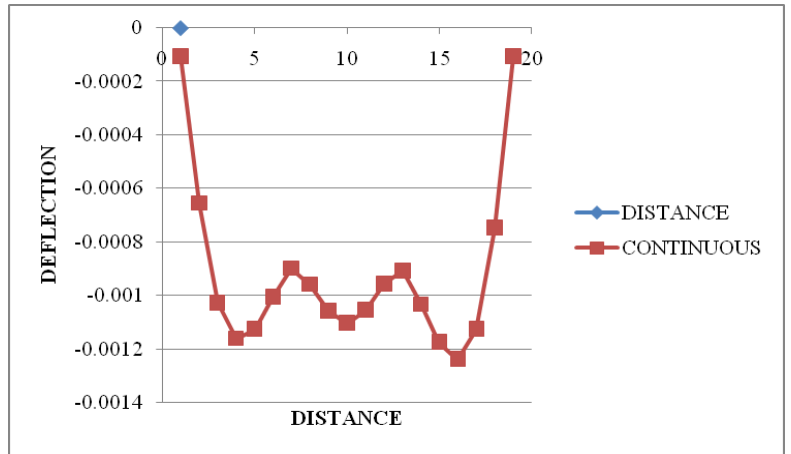

Chart 3.0 - Deflection Vs Distance for Continuous bridge without Pre-stressing force for $51 \mathrm{~m}$ span.

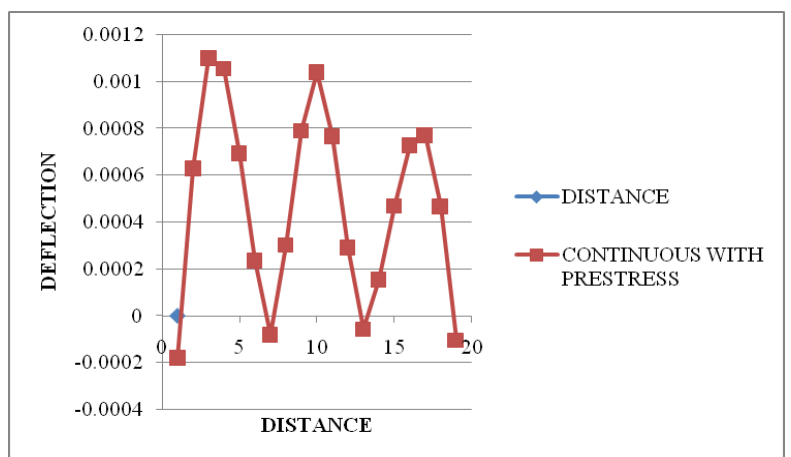

Chart 3.1 - Deflection Vs Distance for Continuous bridge with Pre-stressing force for $51 \mathrm{~m}$ span.

\subsubsection{Overhang}

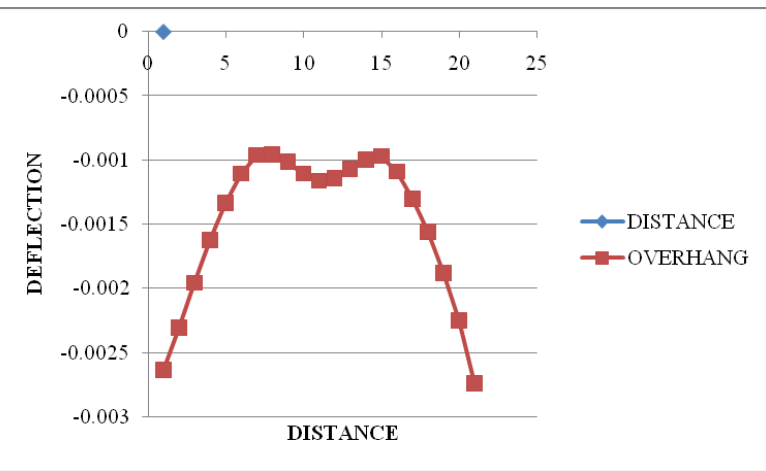

Chart 3.2- Deflection Vs Distance for Overhang bridge without Pre-stressing force for $51 \mathrm{~m}$ span.

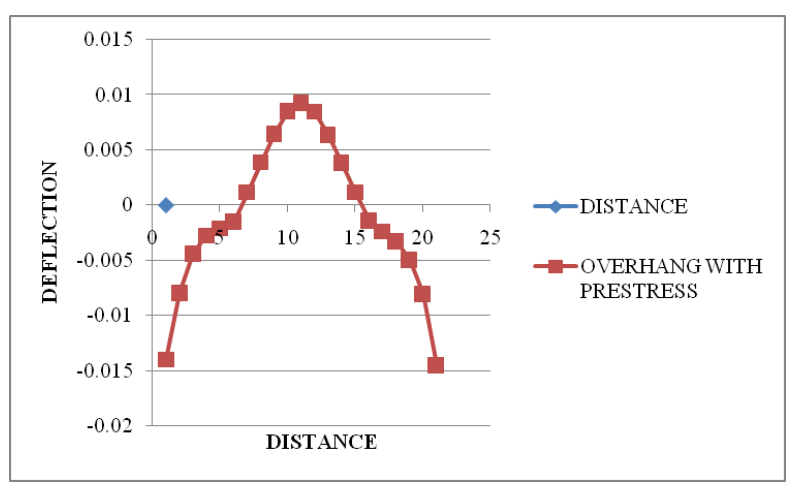

Chart 3.3 - Deflection Vs Distance for Overhang bridge with Pre-stressing force for $51 \mathrm{~m}$ span.

\subsection{SPAN $-60 \mathrm{~m}$}

\subsubsection{Simply Supported}

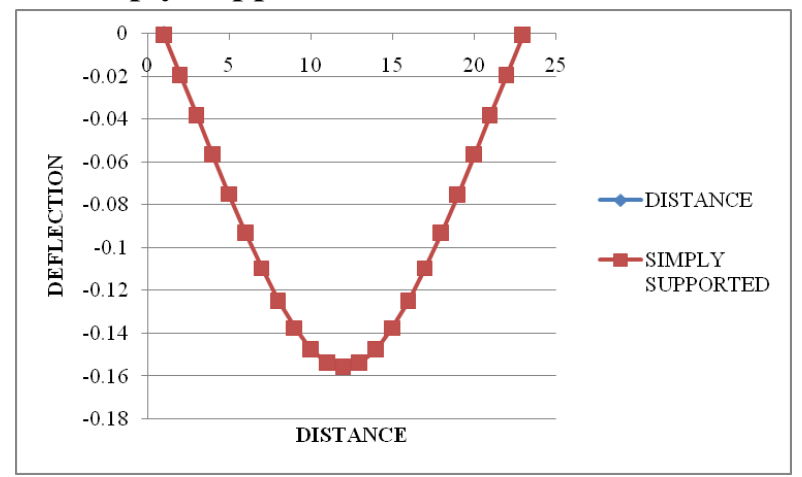

Chart 3.4 - Deflection Vs Distance for Simply supported bridge without Pre-stressing force for $60 \mathrm{~m}$ span.

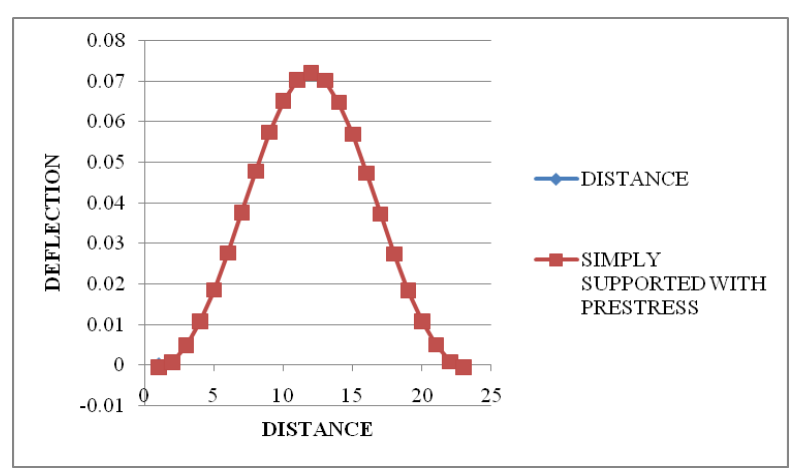

Chart 3.5 - Deflection Vs Distance for Simply supported bridge with Pre-stressing force for $60 \mathrm{~m}$ span. 


\subsubsection{Continuous}

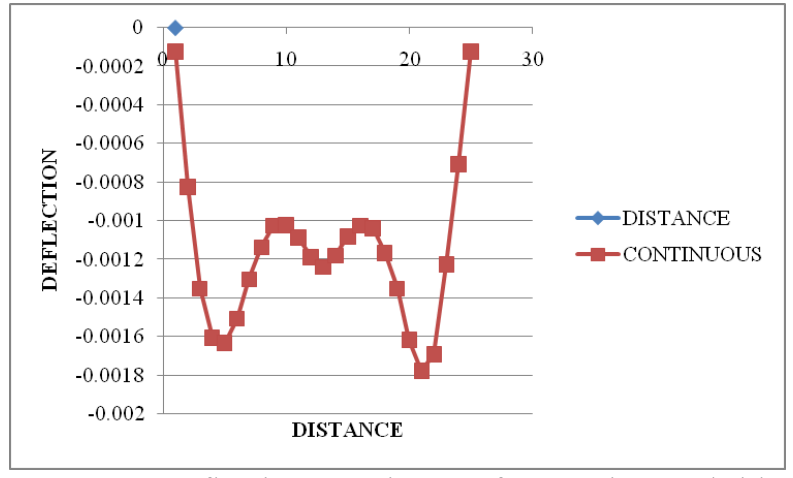

Chart 3.6- Deflection Vs Distance for Continuous bridge without Pre-stressing force for $60 \mathrm{~m}$ span.

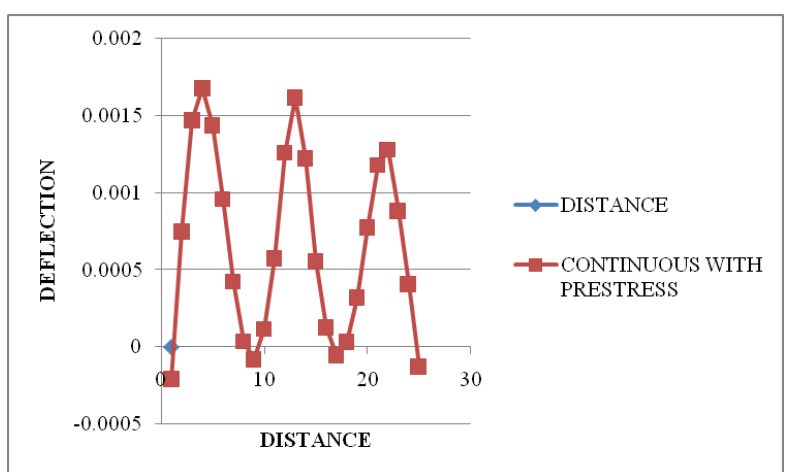

Chart 3.7 - Deflection Vs Distance for Continuous bridge with Pre-stressing force for $60 \mathrm{~m}$ span.

\subsubsection{Overhang}

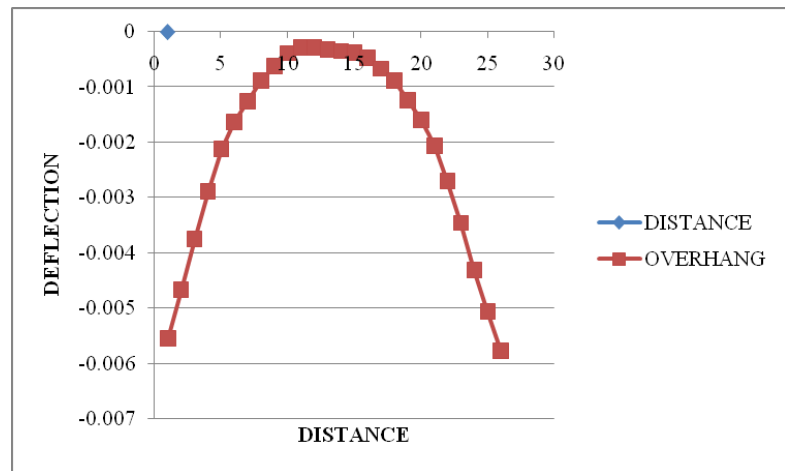

Chart 3.8 - Deflection Vs Distance for Overhang bridge without Pre-stressing force for $60 \mathrm{~m}$ span.

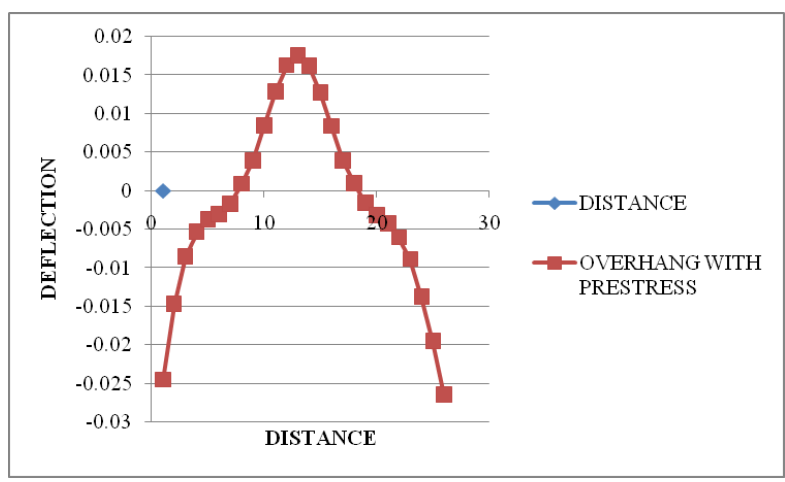

Chart 3.9- Deflection Vs Distance for Overhang bridge with Pre-stressing force for $60 \mathrm{~m}$ span.

\subsection{SPAN - 66m}

5.6.1 Simply Supported

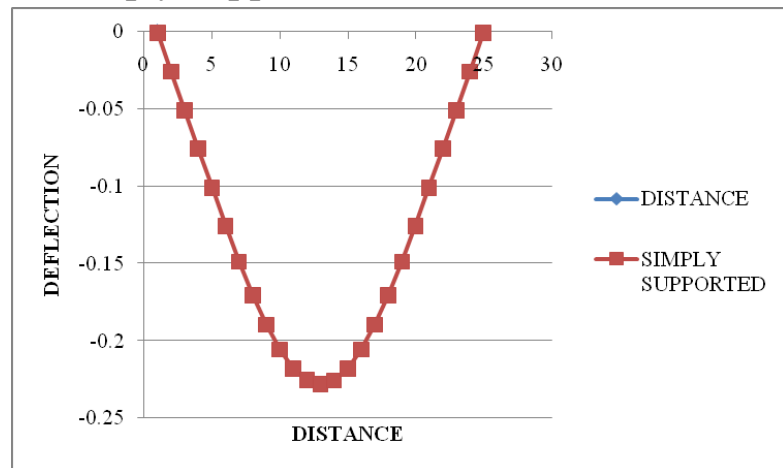

Chart 4.0 - Deflection Vs Distance for Simply supported bridge without Pre-stressing force for $66 \mathrm{~m}$ span.

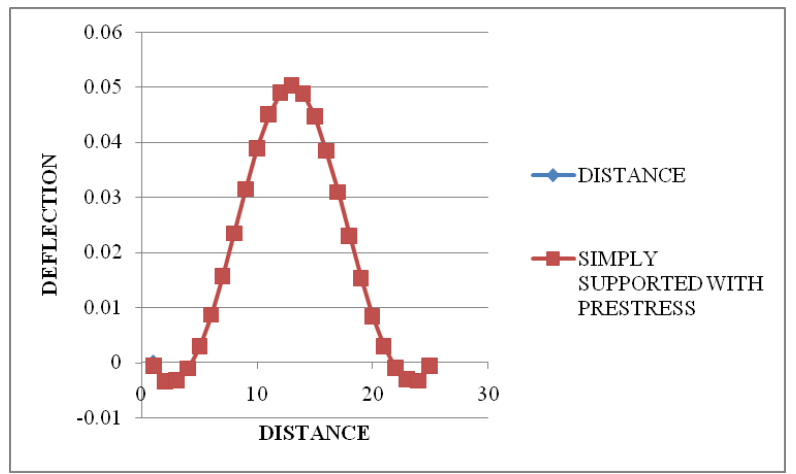

Chart 4.1- Deflection Vs Distance for Simply supported bridge with Pre-stressing force for $66 \mathrm{~m}$ span.

\subsubsection{Continuous}

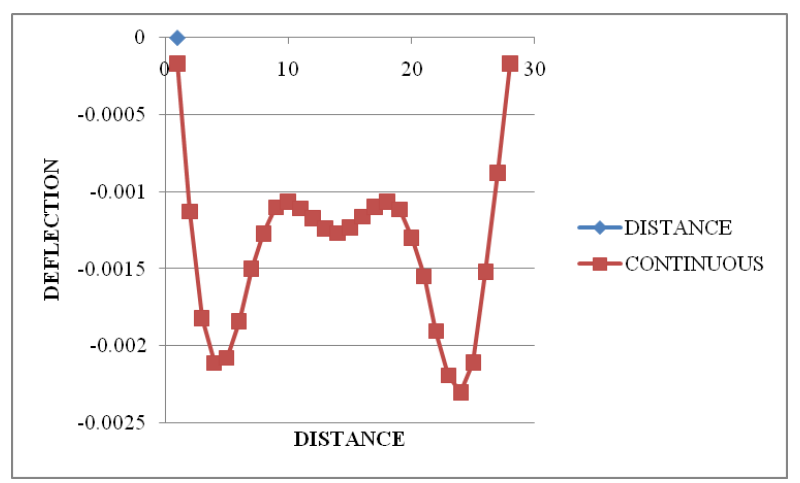

Chart 4.2 - Deflection Vs Distance for Continuous bridge without Pre-stressing force for $66 \mathrm{~m}$ span.

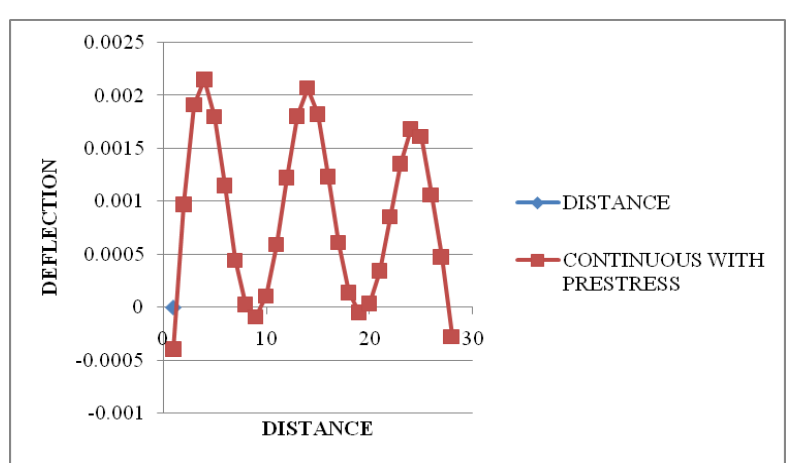

Chart 4.3 - Deflection Vs Distance for Continuous bridge with Pre-stressing force for $66 \mathrm{~m}$ span. 


\subsubsection{Overhang}

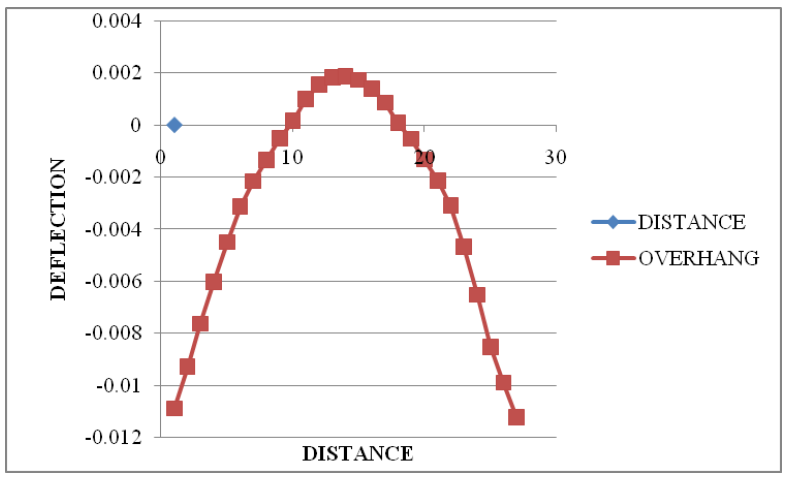

Chart 4.4- Deflection Vs Distance for Overhang bridge without Pre-stressing force for $66 \mathrm{~m}$ span.

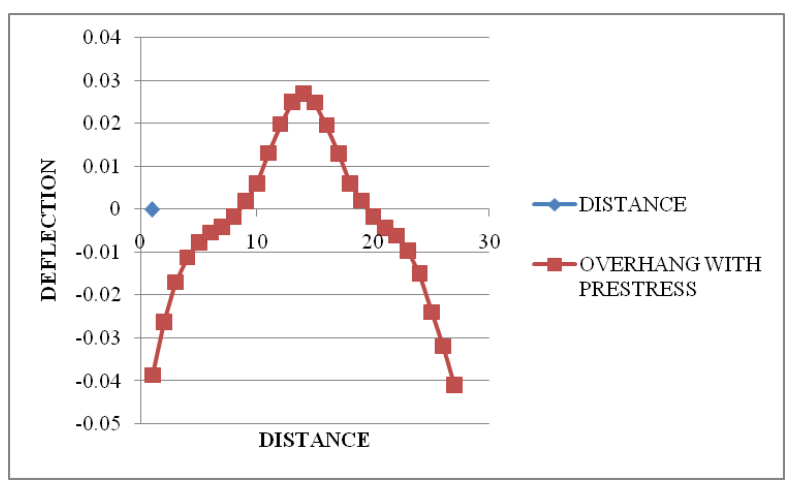

Chart 4.5 - Deflection Vs Distance for Overhang bridge with Pre-stressing force for $66 \mathrm{~m}$ span.

\subsection{SPAN - 75m}

\subsubsection{Simply Supported}

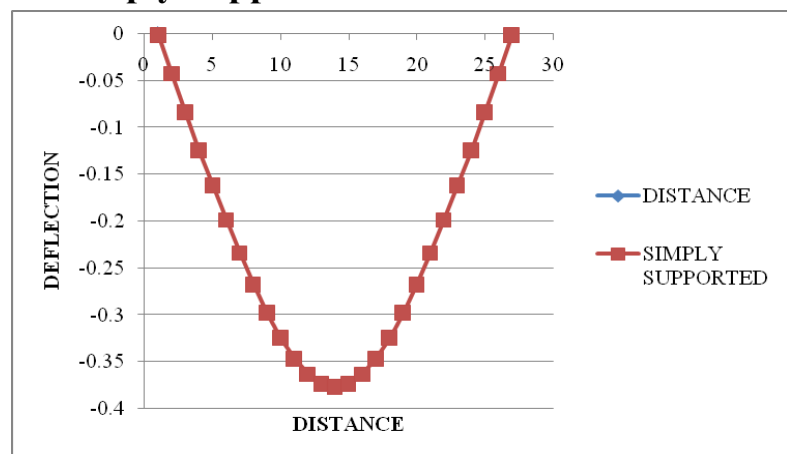

Chart 4.6 - Deflection Vs Distance for Simply supported bridge without Pre-stressing force for $75 \mathrm{~m}$ span.

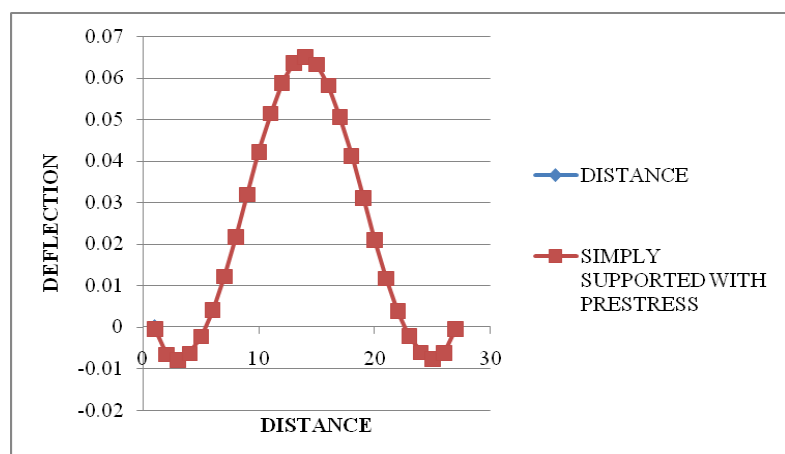

Chart 4.7 - Deflection Vs Distance for Simply supported bridge with Pre-stressing force for $75 \mathrm{~m}$ span.

\subsubsection{Continuous}

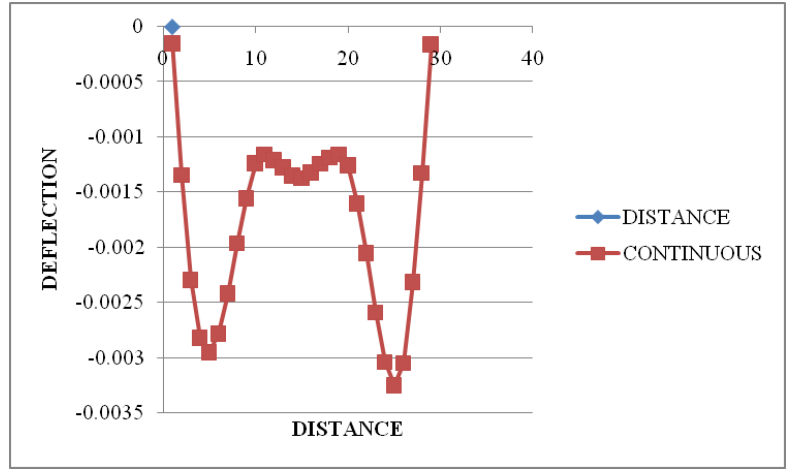

Chart 4.8 - Deflection Vs Distance for Continuous bridge without Pre-stressing force for $75 \mathrm{~m}$ span.

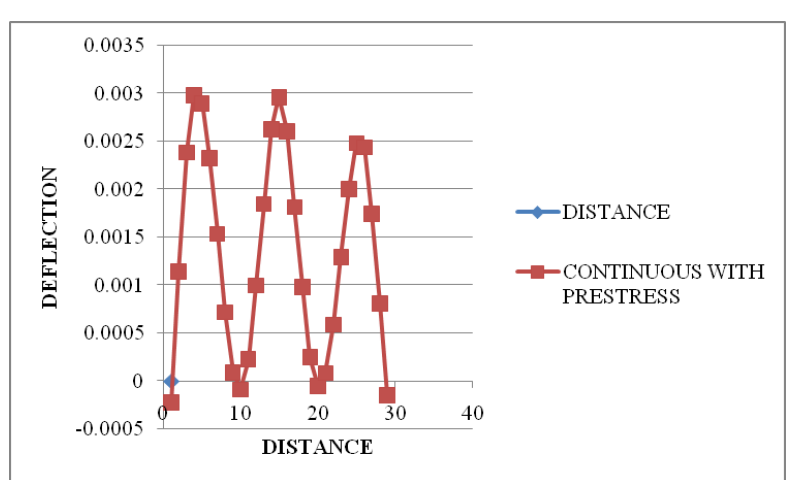

Chart 4.9 - Deflection Vs Distance for Continuous bridge with Pre-stressing force for $75 \mathrm{~m}$ span.

\subsubsection{Overhang}

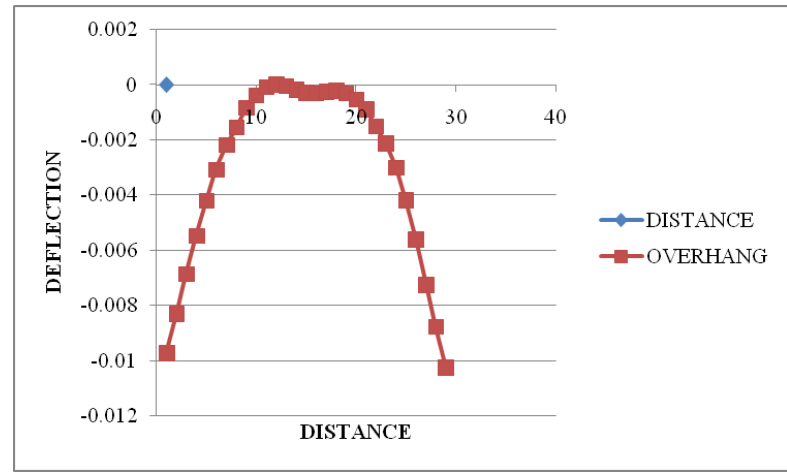

Chart 5.0 - Deflection Vs Distance for Overhang bridge without Pre-stressing force for $75 \mathrm{~m}$ span.

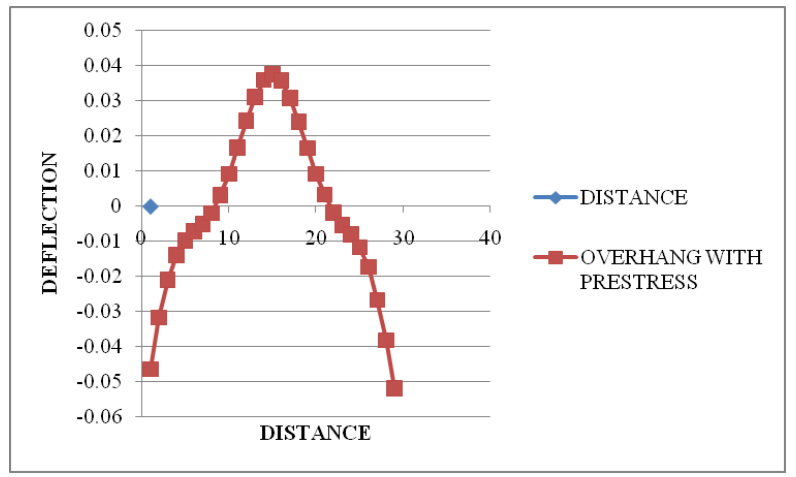

Chart 5.1 - Deflection Vs Distance for Overhang bridge with Pre-stressing force for $75 \mathrm{~m}$ span. 
5.8 SPAN - 81m

\subsubsection{Simply Supported}

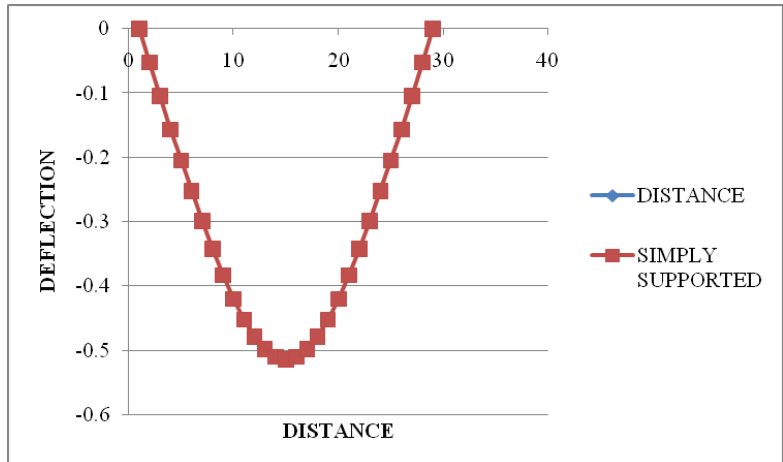

Chart 5.2 - Deflection Vs Distance for Simply supported bridge without Pre-stressing force for $81 \mathrm{~m}$ span.

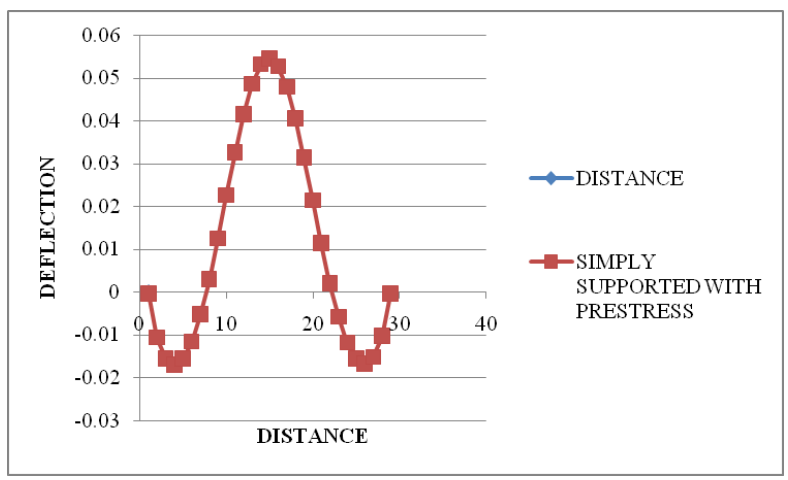

Chart 5.3 - Deflection Vs Distance for Simply supported bridge with Pre-stressing force for $81 \mathrm{~m}$ span.

\subsubsection{Continuous}

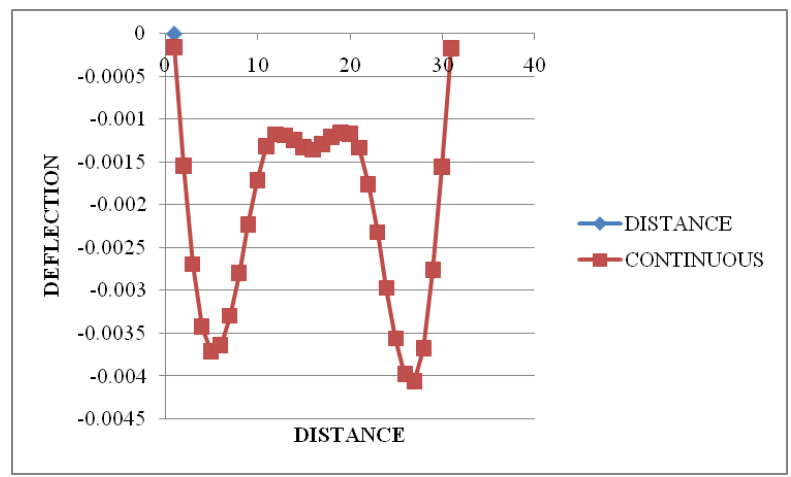

Chart 5.4 - Deflection Vs Distance for Continuous bridge without Pre-stressing force for $81 \mathrm{~m}$ span.

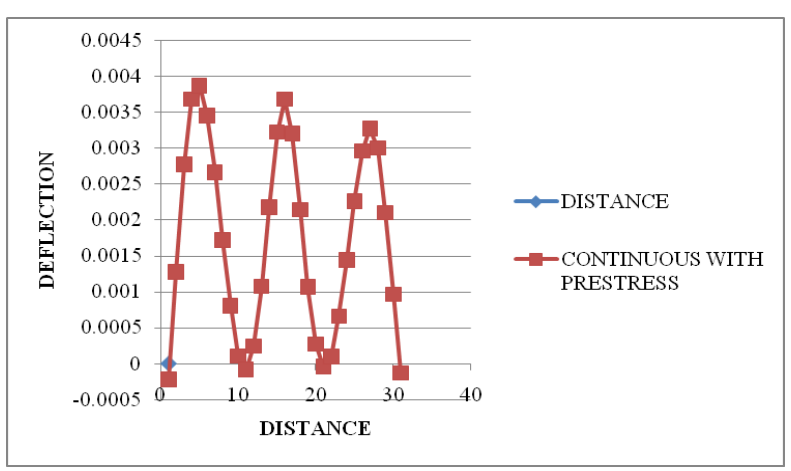

Chart 5.5 - Deflection Vs Distance for Continuous bridge with Pre-stressing force for $81 \mathrm{~m}$ span.

\subsubsection{Overhang}

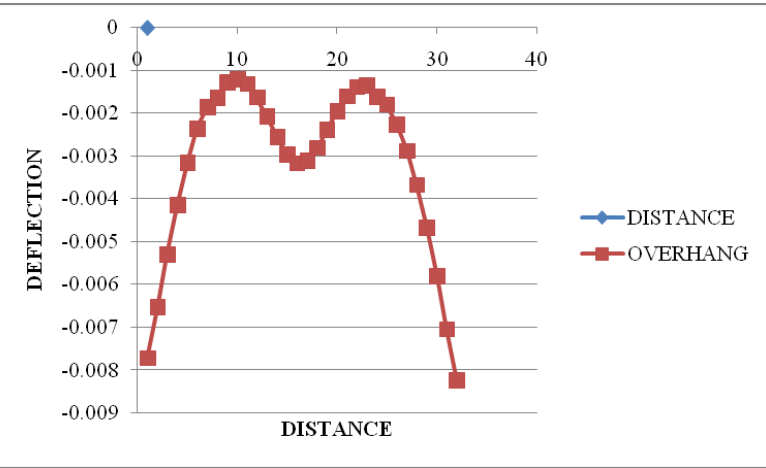

Chart 5.6 - Deflection Vs Distance for Overhang bridge without Pre-stressing force for $81 \mathrm{~m}$ span.

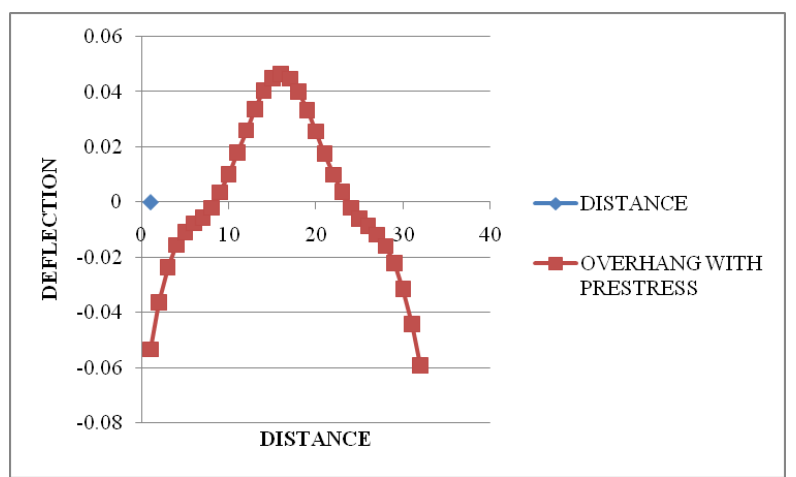

Chart 5.7 - Deflection Vs Distance for Overhang bridge with Pre-stressing force for $81 \mathrm{~m}$ span.

\subsection{SPAN - 90m}

\subsubsection{Simply Supported}

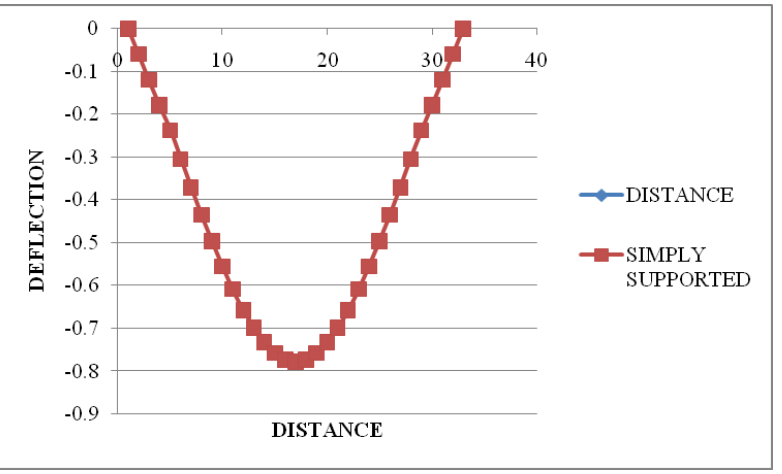

Chart 5.8 - Deflection Vs Distance for Simply supported bridge without Pre-stressing force for $90 \mathrm{~m}$ span.

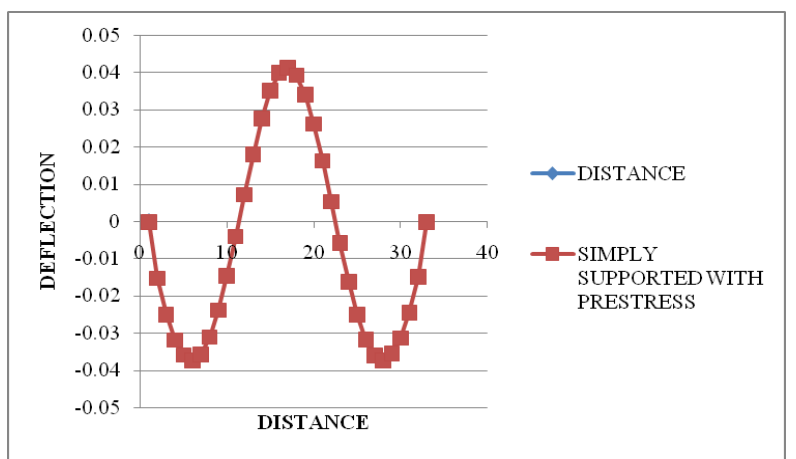

Chart 5.9 - Deflection Vs Distance for Simply supported bridge with Pre-stressing force for $90 \mathrm{~m}$ span. 


\subsubsection{Continuous}

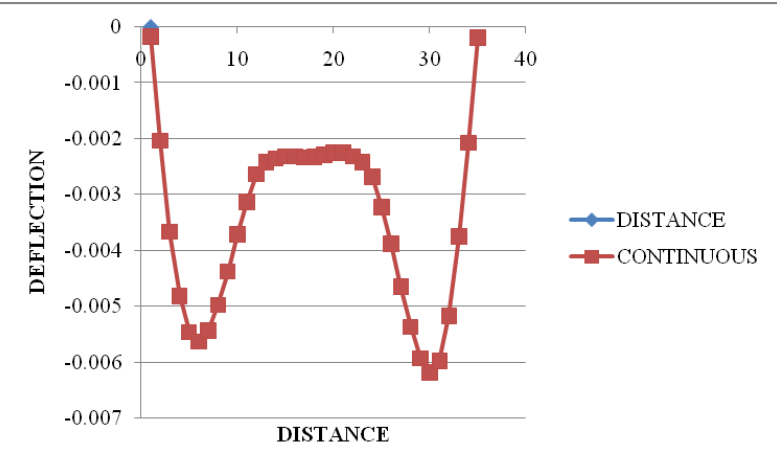

Chart 6.0 - Deflection Vs Distance for Continuous bridge without Pre-stressing force for $90 \mathrm{~m}$ span.

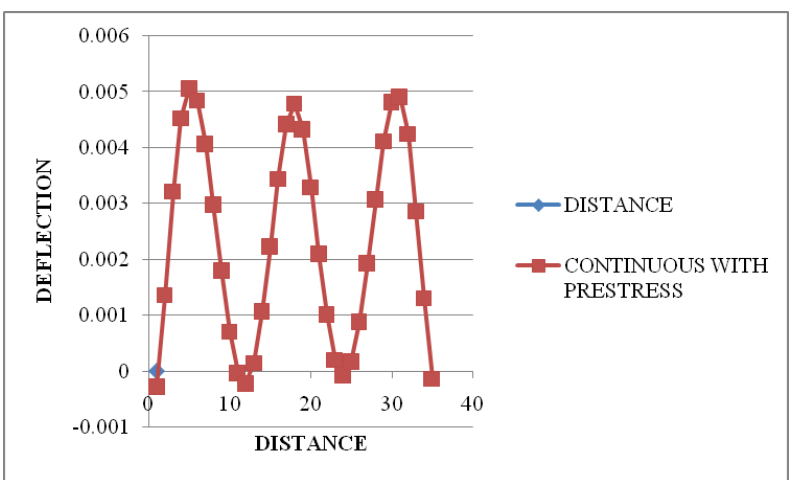

Chart 6.1 - Deflection Vs Distance for Continuous bridge with Pre-stressing force for $90 \mathrm{~m}$ span.

\subsubsection{Overhang}

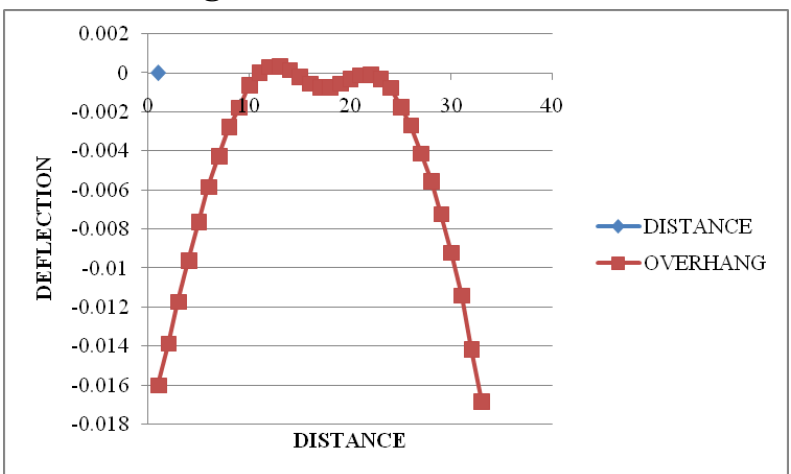

Chart 6.2 - Deflection Vs Distance for Overhang bridge without Pre-stressing force for $90 \mathrm{~m}$ span.

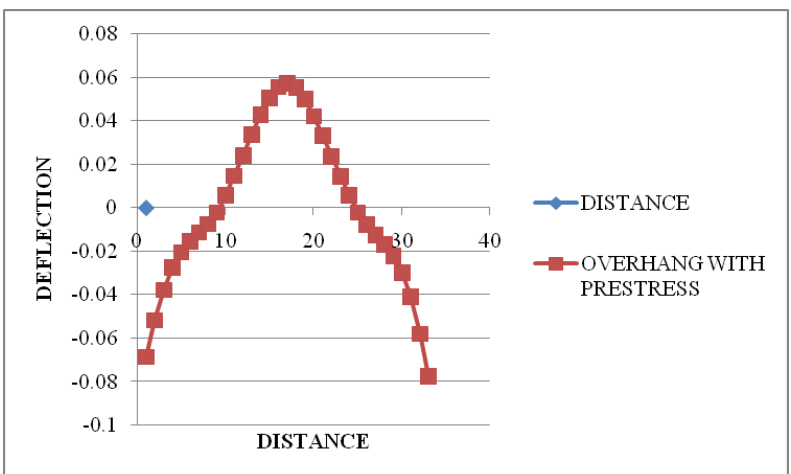

Chart 6.3 - Deflection Vs Distance for Overhang bridge with Pre-stressing force for $90 \mathrm{~m}$ span.

\subsection{SPAN - 96m}

\subsubsection{Simply Supported}

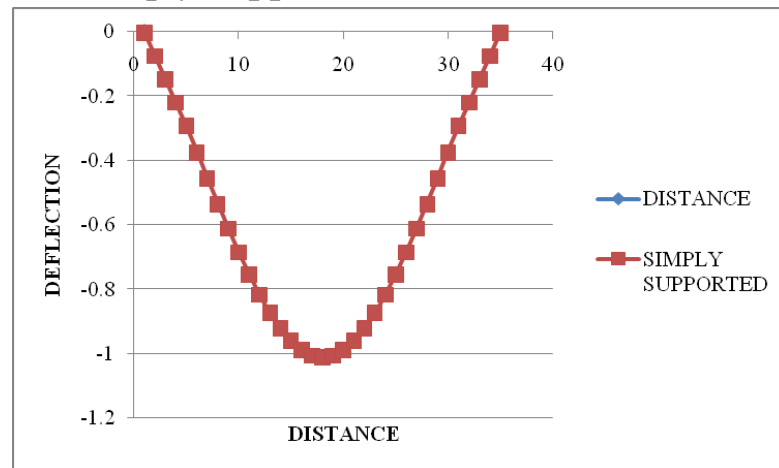

Chart 6.4 - Deflection Vs Distance for Simply supported bridge without Pre-stressing force for $96 \mathrm{~m}$ span.

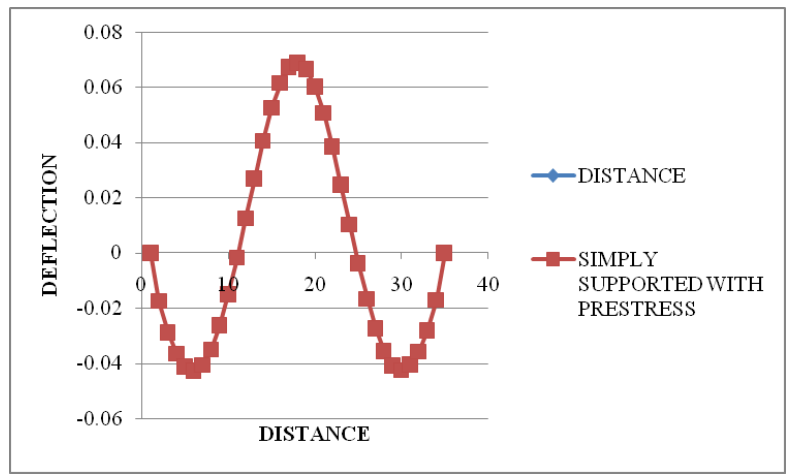

Chart 6.5 - Deflection Vs Distance for Simply supported bridge with Pre-stressing force for $96 \mathrm{~m}$ span.

\subsubsection{Continuous}

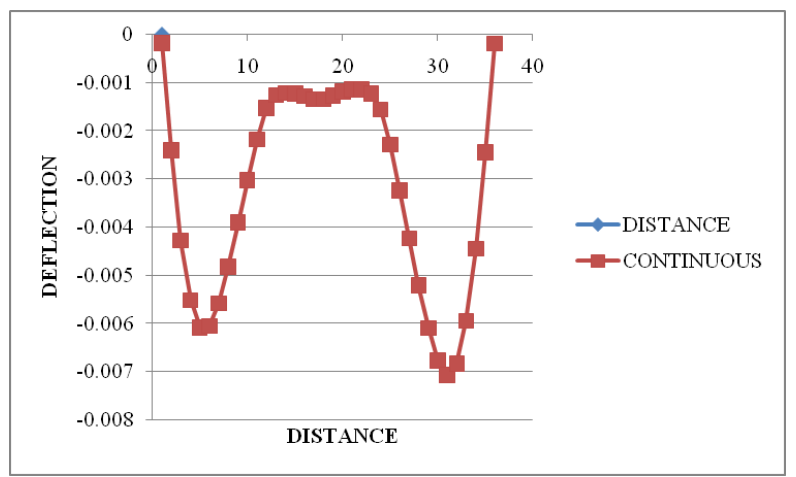

Chart 6.6 - Deflection Vs Distance for Continuous bridge without Pre-stressing force for $96 \mathrm{~m}$ span.

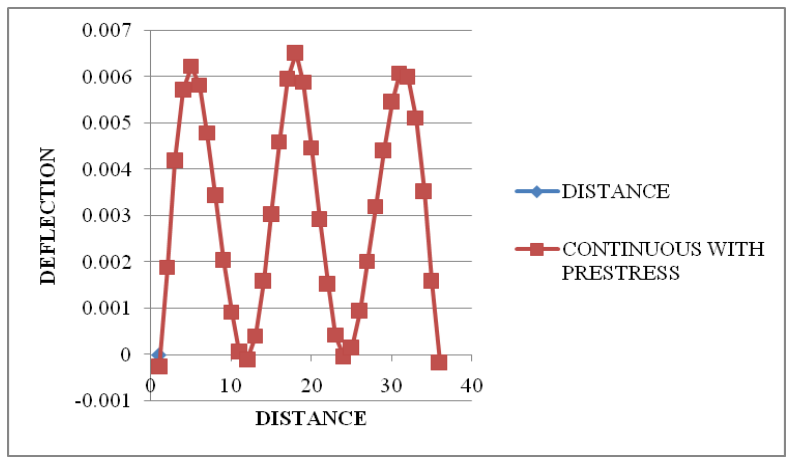

Chart 6.7 - Deflection Vs Distance for Continuous bridge with Pre-stressing force for $96 \mathrm{~m}$ span. 


\subsubsection{Overhang}

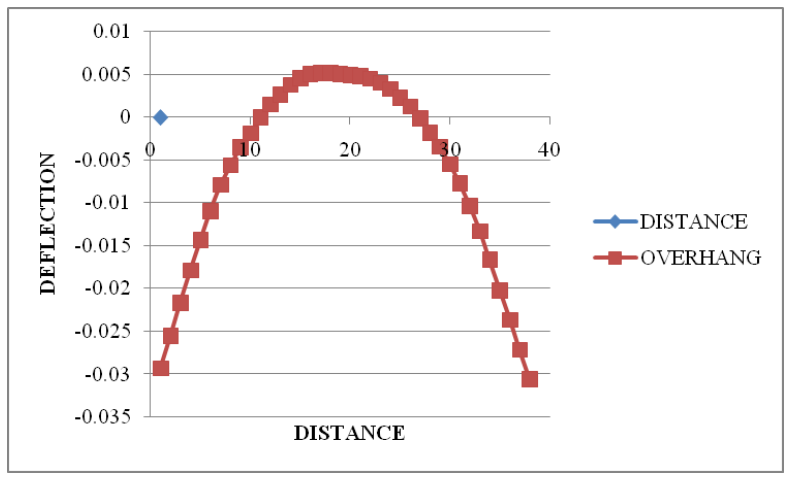

Chart 6.8 - Deflection Vs Distance for Overhang bridge without Pre-stressing force for $96 \mathrm{~m}$ span.

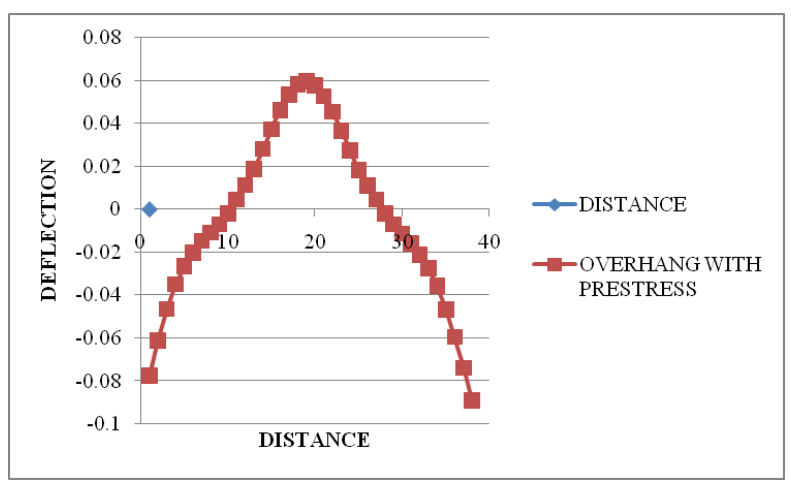

Chart 6.9 - Deflection Vs Distance for Overhang bridge with Pre-stressing force for $96 \mathrm{~m}$ span.

\subsection{SPAN - 105m}

\subsubsection{Simply Supported}

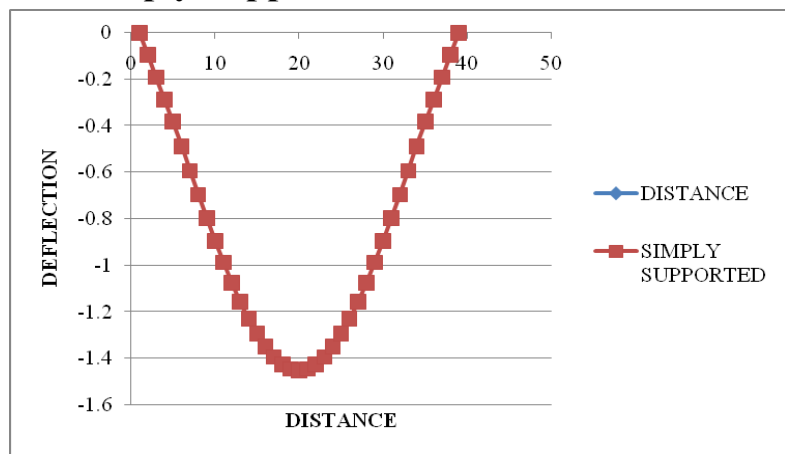

Chart 7.0 - Deflection Vs Distance for Simply supported bridge without Pre-stressing force for $105 \mathrm{~m}$ span.

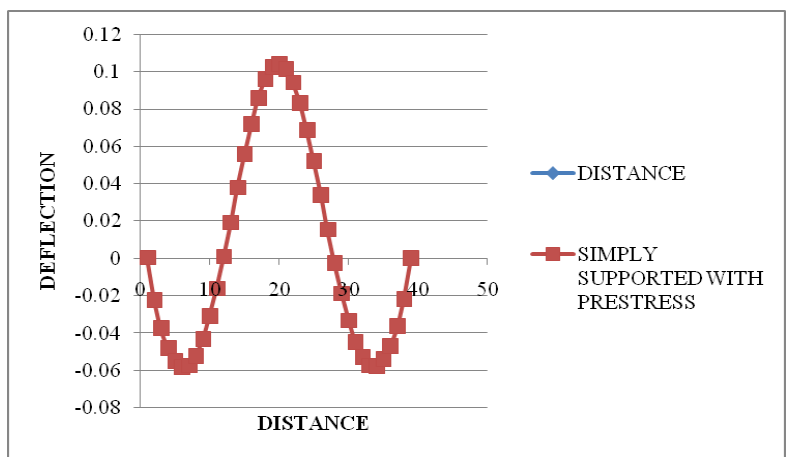

Chart 7.1 - Deflection Vs Distance for Simply supported bridge with Pre-stressing force for $105 \mathrm{~m}$ span.

\subsubsection{Continuous}

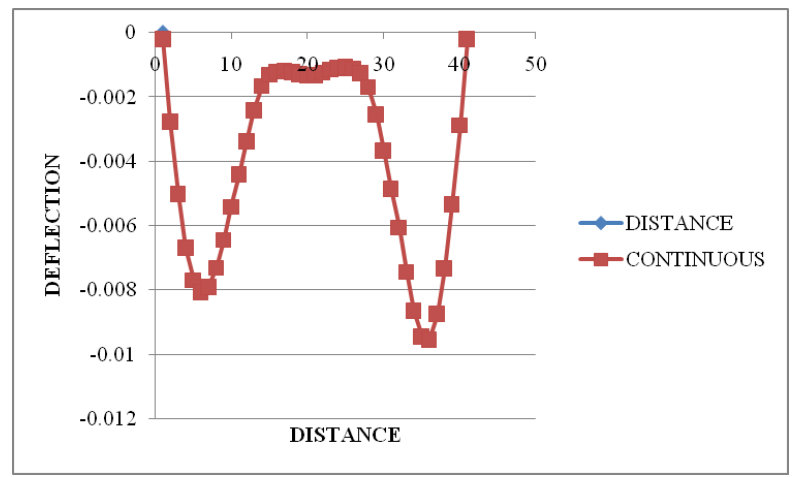

Chart 7.2 - Deflection Vs Distance for Continuous bridge without Pre-stressing force for $105 \mathrm{~m}$ span.

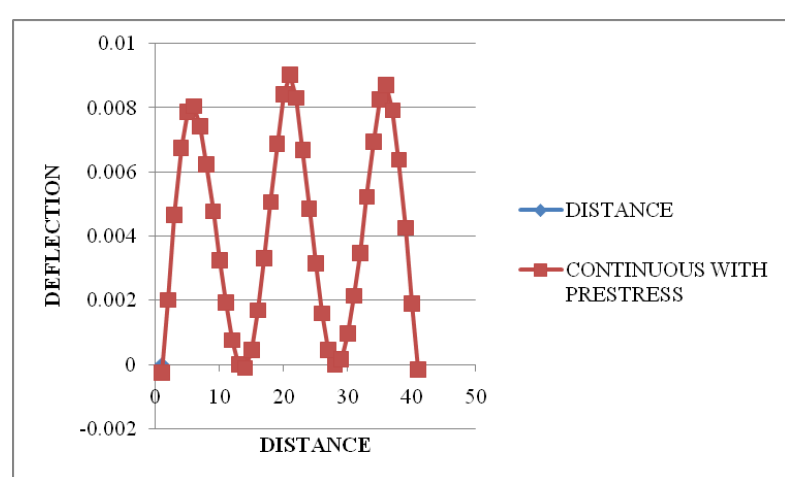

Chart 7.3 - Deflection Vs Distance for Continuous bridge with Pre-stressing force for $105 \mathrm{~m}$ span.

\subsubsection{Overhang}

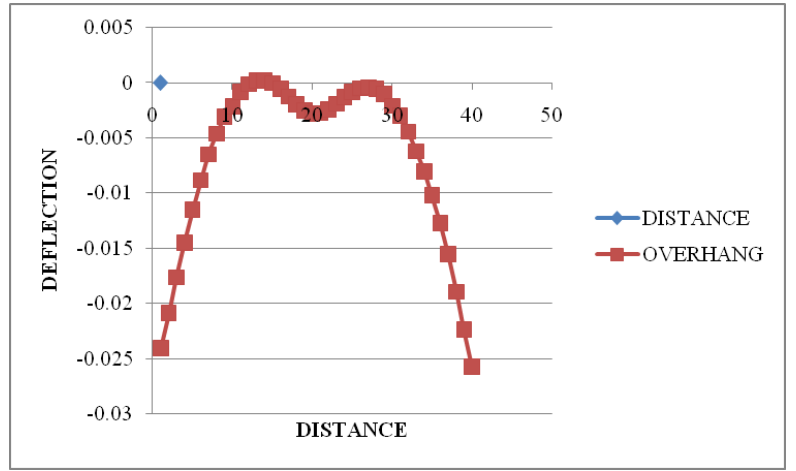

Chart 7.4 - Deflection Vs Distance for Overhang bridge without Pre-stressing force for $105 \mathrm{~m}$ span.

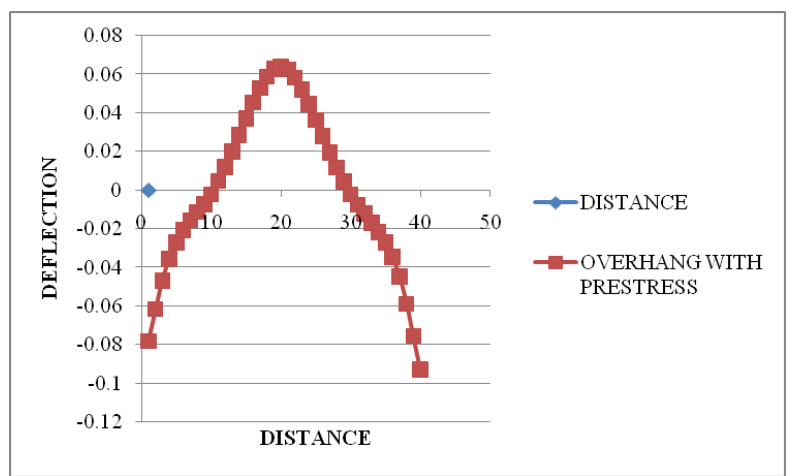

Chart 7.5 - Deflection Vs Distance for Overhang bridge with Pre-stressing force for $105 \mathrm{~m}$ span. 


\subsection{SPAN - 111m}

\subsubsection{Simply Supported}

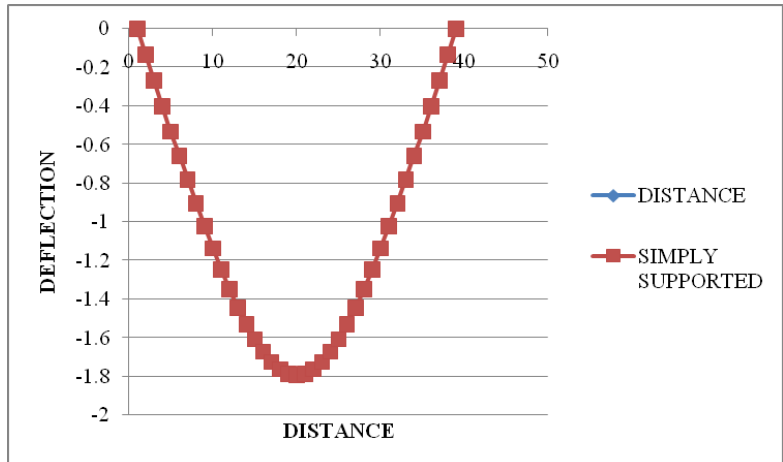

Chart 7.6 - Deflection Vs Distance for Simply supported bridge without Pre-stressing force for $111 \mathrm{~m}$ span.

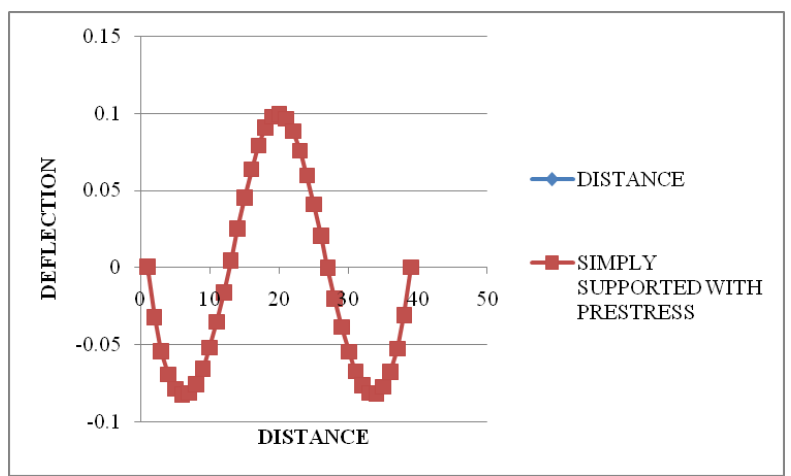

Chart 7.7 - Deflection Vs Distance for Simply supported bridge with Pre-stressing force for $111 \mathrm{~m}$ span.

\subsubsection{Continuous}

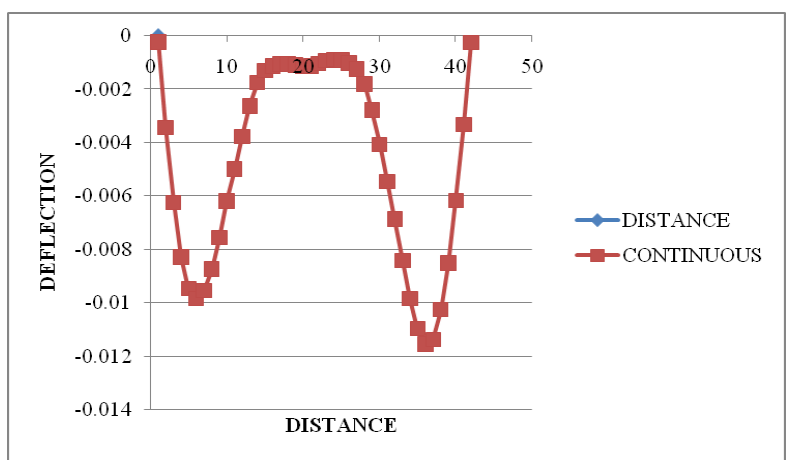

Chart 7.8 - Deflection Vs Distance for Continuous bridge without Pre-stressing force for $111 \mathrm{~m}$ span.

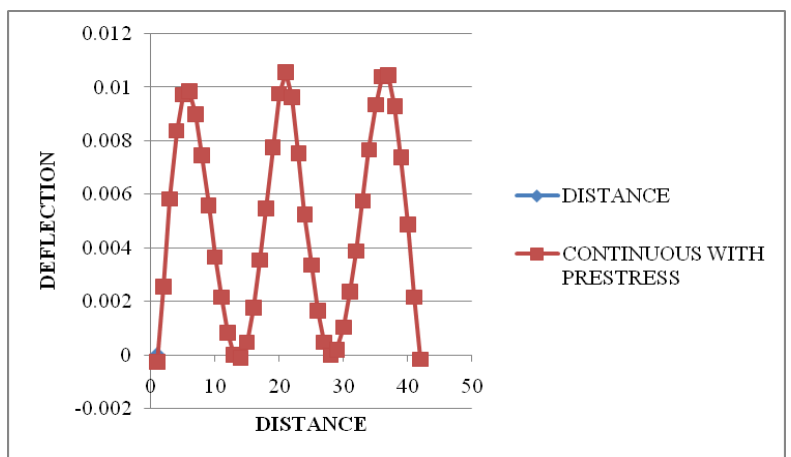

Chart 7.9 - Deflection Vs Distance for Continuous bridge with Pre-stressing force for $111 \mathrm{~m}$ span.

\subsubsection{Overhang}

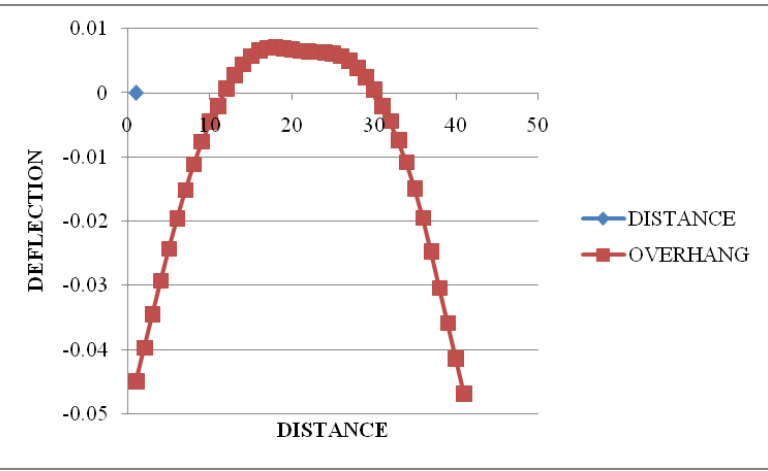

Chart 8.0 - Deflection Vs Distance for Overhang bridge without Pre-stressing force for $111 \mathrm{~m}$ span.

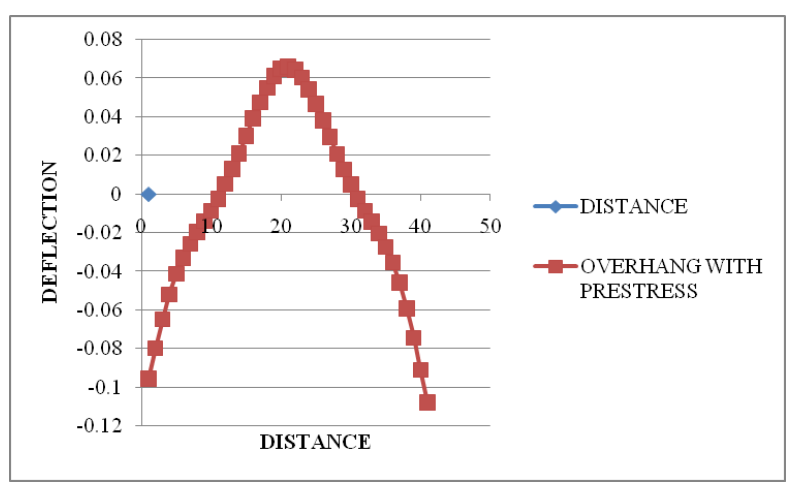

Chart 8.1 - Deflection Vs Distance for Overhang bridge with Pre-stressing force for $111 \mathrm{~m}$ span.

\subsection{SPAN - 120m}

\subsubsection{Simply Supported}

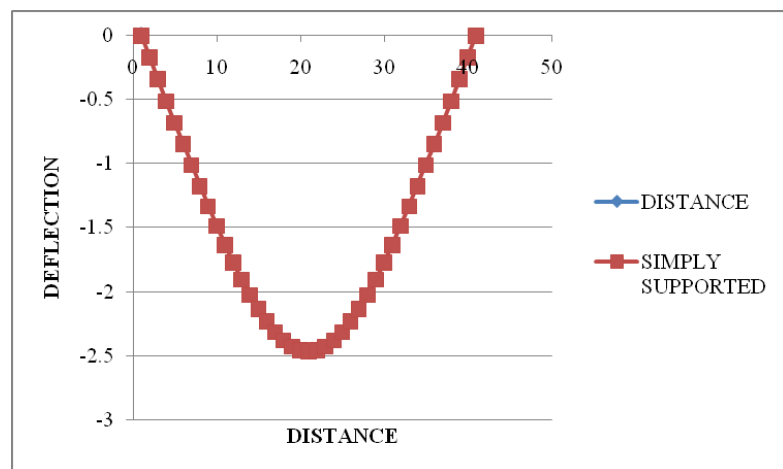

Chart 8.2 - Deflection Vs Distance for Simply supported bridge without Pre-stressing force for $120 \mathrm{~m}$ span.

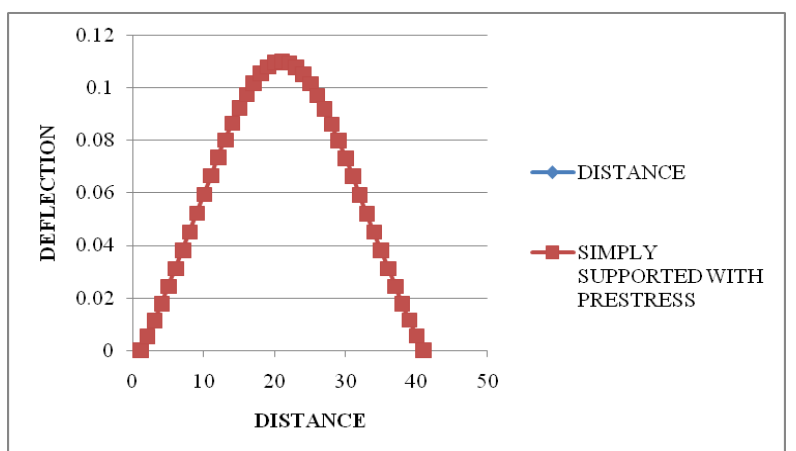

Chart 8.3 - Deflection Vs Distance for Simply supported bridge with Pre-stressing force for $120 \mathrm{~m}$ span. 


\subsubsection{Continuous}

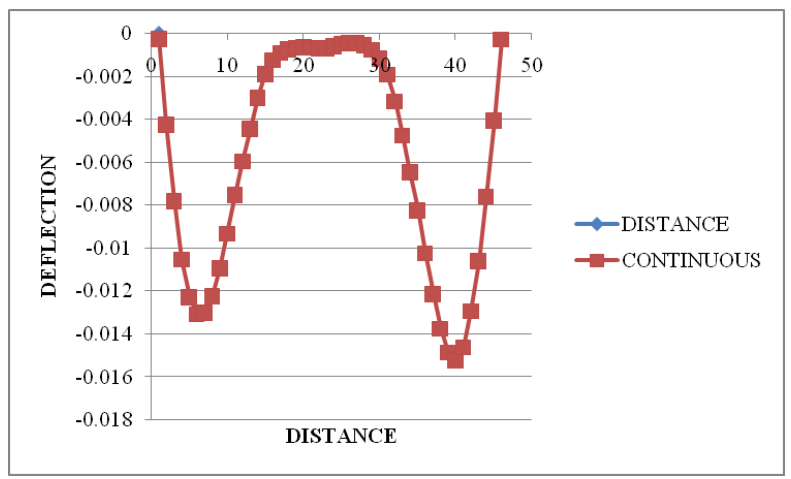

Chart 8.4 - Deflection Vs Distance for Continuous bridge without Pre-stressing force for $120 \mathrm{~m}$ span.

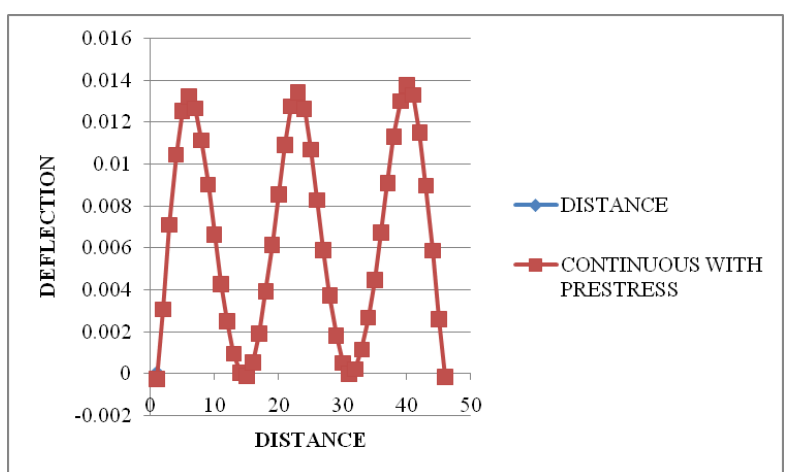

Chart 8.5 - Deflection Vs Distance for Continuous bridge with Pre-stressing force for $120 \mathrm{~m}$ span.

\subsubsection{Overhang}

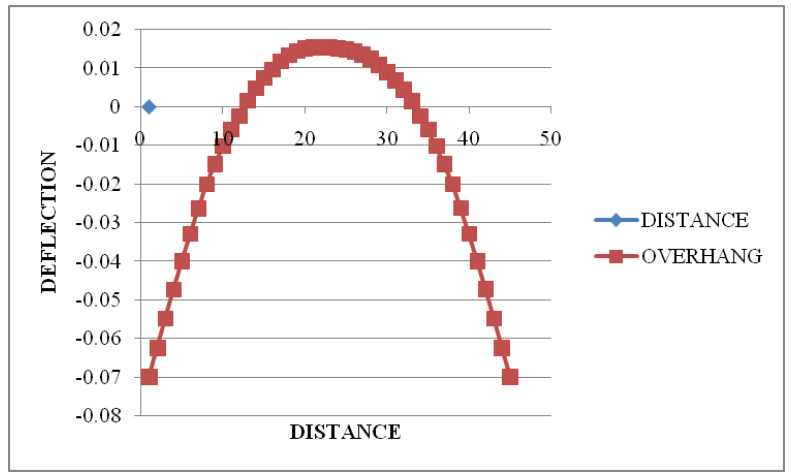

Chart 8.6 - Deflection Vs Distance for Overhang bridge without Pre-stressing force for $120 \mathrm{~m}$ span.

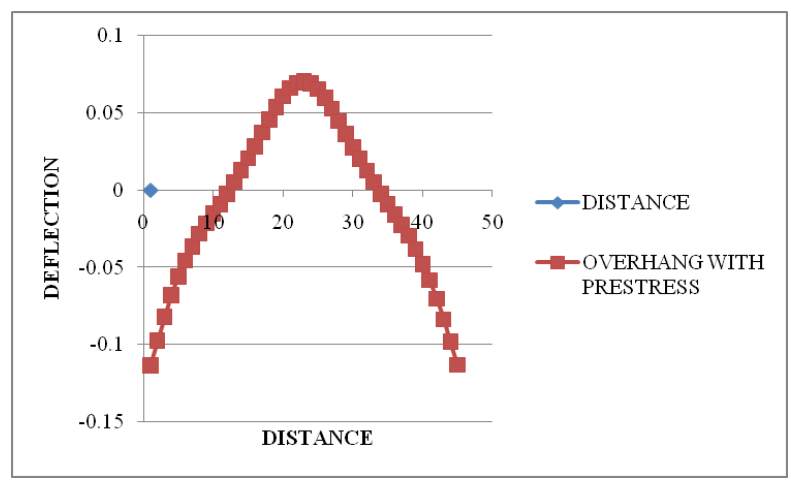

Chart 8.7 - Deflection Vs Distance for Overhang bridge with Pre-stressing force for $120 \mathrm{~m}$ span.

\subsection{Maximum Deflection for Simply Supported} Bridges

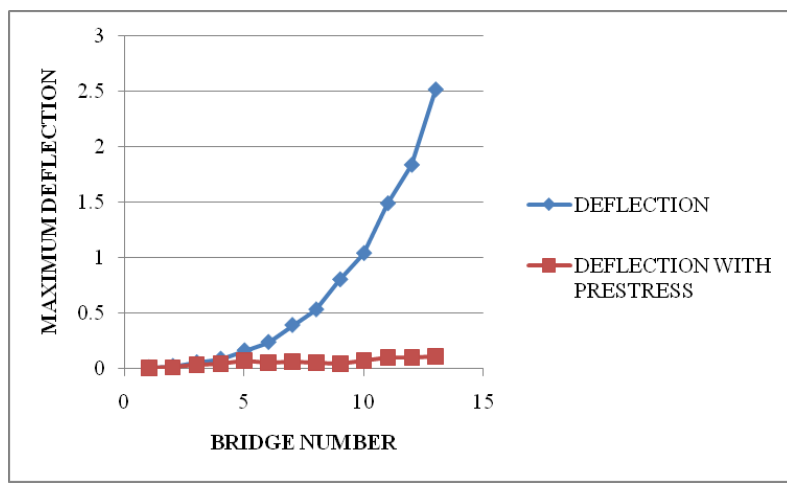

Chart 8.8 - Maximum Deflection Vs Bridge number for Simply supported bridges with and without Pre-stressing force.

Table 1.1 - Maximum Deflection for Simply supported bridges

\begin{tabular}{|c|c|c|c|c|c|}
\hline $\begin{array}{l}\text { Brid } \\
\text { ge } \\
\text { No. }\end{array}$ & $\begin{array}{l}\text { Spa } \\
\text { n } \\
\text { (m) }\end{array}$ & $\begin{array}{l}\text { Deflecti } \\
\text { on } \\
\text { without } \\
\text { pre- } \\
\text { stress } \\
\text { (m) }\end{array}$ & $\begin{array}{l}\text { Deflecti } \\
\text { on with } \\
\text { Pre- } \\
\text { stress } \\
\text { (m) }\end{array}$ & $\begin{array}{l}\text { Permiss- } \\
\text { ible } \\
\text { Deflecti } \\
\text { on } \\
\text { accordin } \\
\text { g to } \\
\text { IS112: } \\
2011 \\
\text { (m) }\end{array}$ & $\begin{array}{l}\text { Pre- } \\
\text { stressin } \\
\text { g force } \\
\text { applied } \\
(\mathbf{k N})\end{array}$ \\
\hline 1 & 30 & -0.0122 & 0.00738 & 0.0375 & 20566 \\
\hline 2 & 36 & -0.0235 & 0.0126 & 0.045 & 28900 \\
\hline 3 & 45 & -0.0562 & 0.0343 & 0.05625 & 48699 \\
\hline 4 & 51 & -0.0881 & 0.0465 & 0.06375 & 60313 \\
\hline 5 & 60 & -0.1644 & 0.0722 & 0.075 & 79215 \\
\hline 6 & 66 & -0.2393 & 0.0503 & 0.0825 & 80000 \\
\hline 7 & 75 & -0.3925 & 0.0651 & 0.09375 & 100000 \\
\hline 8 & 81 & -0.5328 & 0.0546 & 0.10125 & 110000 \\
\hline 9 & 90 & -0.8031 & 0.048 & 0.1125 & 130000 \\
\hline 10 & 96 & -1.0392 & 0.069 & 0.12 & 150000 \\
\hline 11 & 105 & -1.487 & 0.104 & 0.13125 & 180000 \\
\hline 12 & 111 & -1.8335 & 0.0997 & 0.13875 & 200000 \\
\hline 13 & 120 & -2.51 & 0.11 & 0.15 & 10000 \\
\hline
\end{tabular}

\subsection{Maximum Deflection For Continuous Bridges}

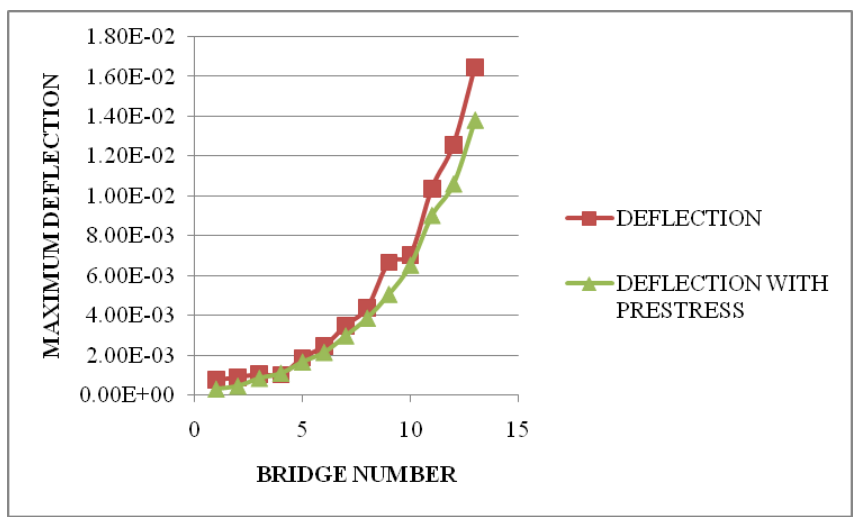

Chart 8.9 - Maximum Deflection Vs Bridge number for Continuous bridges with and without Pre-stressing force. 
Table 1.2 - Maximum Deflection for Continuous bridges

\begin{tabular}{|c|c|c|c|c|c|}
\hline Bridge No. & $\operatorname{Span}(m)$ & $\begin{array}{l}\begin{array}{l}\text { Deflection } \\
\text { without } \\
\text { stress (m) }\end{array} \text { pre- } \\
\end{array}$ & $\begin{array}{l}\text { Deflection With } \\
\text { pre-stress (m) }\end{array}$ & $\begin{array}{l}\text { Permiss-ible } \\
\text { Deflection } \\
\text { according to } \\
\text { IS112: } 2011(\mathrm{~m})\end{array}$ & $\begin{array}{l}\text { Pre-stressing } \\
\text { Force applied(kN) }\end{array}$ \\
\hline 1 & 30 & $7.75 \mathrm{E}-04$ & $3.11 \mathrm{E}-04$ & 0.0125 & 2585.853 \\
\hline 2 & 36 & $9.03 \mathrm{E}-04$ & $4.61 \mathrm{E}-04$ & 0.015 & 3308.077 \\
\hline 3 & 45 & $1.06 \mathrm{E}-03$ & $8.52 \mathrm{E}-04$ & 0.01875 & 4518.352 \\
\hline 4 & 51 & $1.03 \mathrm{E}-03$ & $1.10 \mathrm{E}-03$ & 0.02125 & 5228.439 \\
\hline 5 & 60 & $1.89 \mathrm{E}-03$ & $1.67 \mathrm{E}-03$ & 0.025 & 6663.56 \\
\hline 6 & 66 & $2.47 \mathrm{E}-03$ & $2.15 \mathrm{E}-03$ & 0.0275 & 7647.746 \\
\hline 7 & 75 & $3.51 \mathrm{E}-03$ & $2.98 \mathrm{E}-03$ & 0.03125 & 9270.538 \\
\hline 8 & 81 & $4.41 \mathrm{E}-03$ & $3.87 \mathrm{E}-03$ & 0.03375 & 10570.54 \\
\hline 9 & 90 & $6.68 \mathrm{E}-03$ & $5.06 \mathrm{E}-03$ & 0.0375 & 12606.186 \\
\hline 10 & 96 & $7.07 \mathrm{E}-03$ & $6.53 \mathrm{E}-03$ & 0.04 & 14460.382 \\
\hline 11 & 105 & 0.0104 & $9.02 \mathrm{E}-03$ & 0.04375 & 17208.913 \\
\hline 12 & 111 & 0.0126 & 0.0106 & 0.04625 & 18964.575 \\
\hline 13 & 120 & 0.0165 & 0.0138 & 0.05 & 21735.196 \\
\hline
\end{tabular}

\subsection{Maximum Deflection For Overhang Bridges}
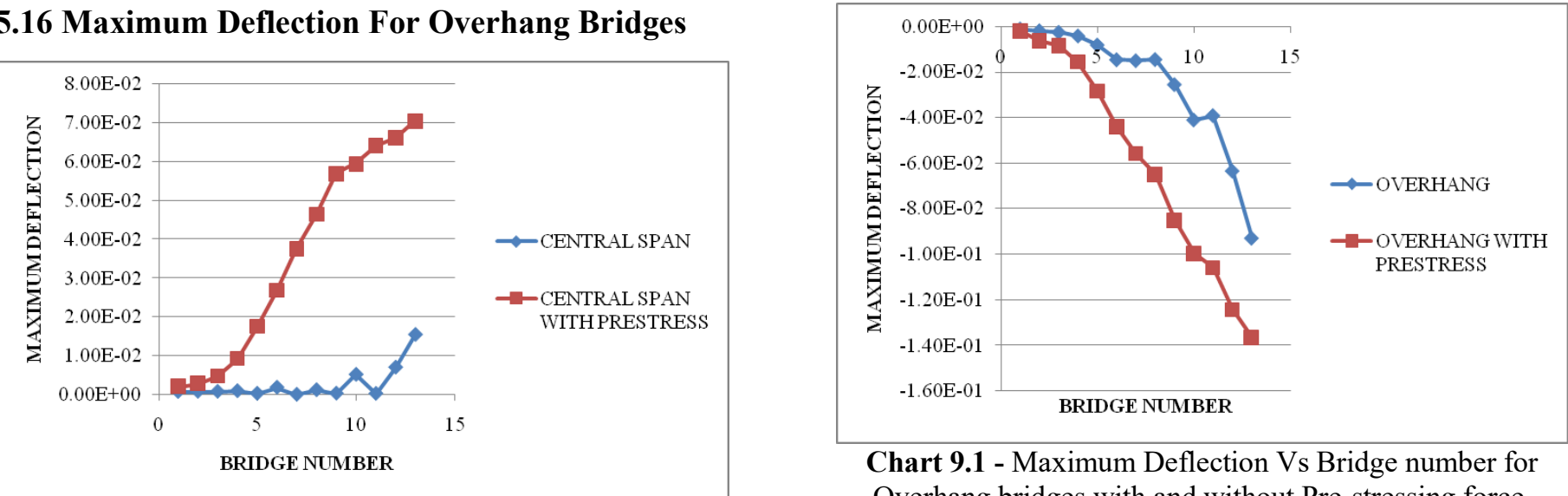

Chart 9.0 - Maximum Deflection Vs Bridge number for

Chart 9.1 - Maximum Deflection Vs Bridge number for Overhang bridges with and without Pre-stressing force.

Overhang bridges (central span) with and without Prestressing force.

Table 1.3 - Maximum Deflection for Overhang bridges

\begin{tabular}{|c|c|c|c|c|c|c|c|c|}
\hline \multirow{2}{*}{$\begin{array}{l}\text { Bri } \\
\text { dge } \\
\text { No. }\end{array}$} & \multirow{2}{*}{$\begin{array}{l}\text { Span } \\
\text { (m) }\end{array}$} & \multirow{2}{*}{$\begin{array}{l}\text { Deflec-tion } \\
\text { with } \\
\text { Out pre-stress } \\
\text { (b/w support) } \\
\text { (m) } \\
\end{array}$} & \multirow{2}{*}{$\begin{array}{l}\text { Deflec-tion } \\
\text { with pre- } \\
\text { stress } \\
\text { (b/w } \\
\text { support) (m) }\end{array}$} & \multirow{2}{*}{ 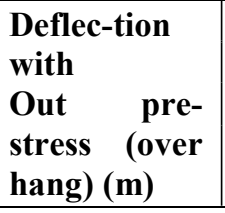 } & \multirow{2}{*}{$\begin{array}{l}\text { Deflec-tion } \\
\text { with pre- } \\
\text { stress (over } \\
\text { hang) (m) }\end{array}$} & \multicolumn{2}{|c|}{$\begin{array}{l}\text { Permissible } \\
\text { deflection according } \\
\text { to IS112:2011 (m) }\end{array}$} & \multirow{2}{*}{$\begin{array}{l}\text { Pre- } \\
\text { stressin } \\
\mathrm{g} \text { force } \\
\text { applied } \\
(\mathbf{k N})\end{array}$} \\
\hline & & & & & & $\begin{array}{l}\text { B/w } \\
\text { support }\end{array}$ & $\begin{array}{l}\text { Over } \\
\text { hang }\end{array}$ & \\
\hline 1 & 30 & $-7.50 \mathrm{E}-04$ & $2.05 \mathrm{E}-03$ & $-1.09 \mathrm{E}-03$ & $-2.22 \mathrm{E}-03$ & 0.02 & 0.02 & 7097 \\
\hline 2 & 36 & $-8.00 \mathrm{E}-04$ & $2.81 \mathrm{E}-03$ & $-1.89 \mathrm{E}-03$ & $-6.50 \mathrm{E}-03$ & 0.0225 & 0.03 & 10294 \\
\hline 3 & 45 & $-7.83 \mathrm{E}-04$ & $4.70 \mathrm{E}-03$ & $-2.55 \mathrm{E}-03$ & \begin{tabular}{|l|}
$-8.75 \mathrm{E}-03$ \\
\end{tabular} & 0.03 & 0.04 & 13392 \\
\hline 4 & 51 & $-9.53 \mathrm{E}-04$ & $9.31 \mathrm{E}-03$ & $-4.15 \mathrm{E}-03$ & $-1.58 \mathrm{E}-02$ & 0.0325 & 0.04 & 18255 \\
\hline 5 & 60 & $-2.87 \mathrm{E}-04$ & 0.0176 & $-8.13 \mathrm{E}-03$ & -0.0285 & 0.0375 & 0.05 & 25473 \\
\hline 6 & 66 & $1.86 \mathrm{E}-03$ & $2.69 \mathrm{E}-02$ & -0.0146 & -0.0441 & 0.04 & 0.06 & 31852 \\
\hline 7 & 75 & $1.39 \mathrm{E}-05$ & 0.0376 & -0.015 & -0.0559 & 0.0475 & 0.06 & 37123 \\
\hline 8 & 81 & $-1.20 \mathrm{E}-03$ & 0.0465 & -0.0145 & -0.0651 & 0.0525 & 0.07 & 40722 \\
\hline 9 & 90 & $3.25 \mathrm{E}-04$ & $5.70 \mathrm{E}-02$ & -0.0255 & -0.0852 & 0.0575 & 0.07 & 41000 \\
\hline 10 & 96 & $5.19 \mathrm{E}-03$ & 0.0595 & -0.041 & -0.0996 & 0.06 & 0.08 & 36000 \\
\hline 11 & 105 & $2.61 \mathrm{E}-04$ & 0.0642 & -0.0391 & -0.1059 & 0.0675 & 0.09 & 36000 \\
\hline 12 & 111 & 7.04E-03 & $6.62 \mathrm{E}-02$ & -0.0634 & -0.1243 & 0.07 & 0.09 & 30000 \\
\hline 13 & 120 & -0.0155 & 0.0706 & -0.0929 & -0.1365 & 0.075 & \begin{tabular}{|l|}
0.1 \\
\end{tabular} & 25000 \\
\hline
\end{tabular}




\section{CONCLUSION}

- The Deflection diagram gets inverted after the application of pre-stressing force for Simply Supported and Continuous bridges, whereas it remains the same for Overhang bridges.

- As span increases, there is a major lowering in the deflection after pre-stressing for Simply supported bridges.

- As span increases, there is a slight lowering in the deflection after pre-stressing for Continuous bridges.

- For Overhang bridges, the deflection is maximum when subjected to Pre-stressing.

- After the application of Pre-stressing force, the deflection values reduce gradually for Simply Supported, Continuous and Overhang Bridges respectively.

\section{REFERENCES}

[1] Chetan T Naik, Dr. M. M Achar, K Lakshmi "Analysis and Design of Multi Cell Post-Tensioned PSC Box Girder" India IOSR Journal of Mechanical and Civil Engineering (IOSR-JMCE) e-ISSN: 22781684,p-ISSN: 2320-334X, Volume 12, Issue 4 Ver. VII (Jul. - Aug. 2015), PP 56-64 www.iosrjournals.org

[2] Dr. Husain M. Husain and Mohanned I. Mohammed Hussein - "Finite element analysis of post-tensioned concrete box girders", Journal of Bridge Engg (2007)

[3] Hemalatha A, Ashwin K. N, Dattatreya J.K, S.V.Dinesh "Analysis Of RC Bridge Decks For Selected National And International standard loadings using Finite Element Method" IJRET, ISSN: 23217308.

[4] Mayank Chourasia, Dr. Saleem Akhtar, "Design and Analysis of Prestressed Concrete Box Girder by Finite Element Method (4 Cells \& 1 Cell)" International Journal of Civil and Structural Engineering Research ISSN 2348-7607 (Online) Vol.3, Issue1, pp:(413421), Month: April-September 2015

[5] Patil Yashavant S, Prof. Shinde Sangita B, "Comparitive analysis of box girder birdge with two different codes", ISSN 0976 - 6308 (Print), ISSN 0976 - 6316(Online), Volume 4, Issue 3, May - June (2013), pp. 111-120 C IAEME: www.iaeme.com/ijciet.asp

[6] IRC: 6-2000 "Standards specification and code of practice for road bridges" Indian road congress.

[7] IRC: 18-2000 "Design criteria for pre-stressed concrete road bridges (post-tensioned concrete)" Indian road congress.

[8] "Design of Bridges", Text book by N. Krishna Raju, 4th Edition Oxford \& IBH Publishing Co. Pvt. Ltd.

\section{BIOGRAPHIES}

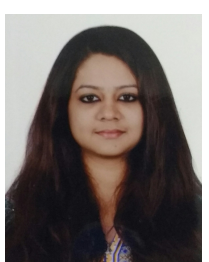

Rashmi R Koushik, MTech Student, Department of Civil Engineering, Global Academy of Technology, Bengaluru 560098

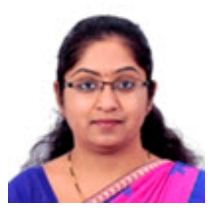

Shilpa Patil, Asst. Professor, Department of Civil Engineering, Global Academy of Technology, Bengaluru -560098

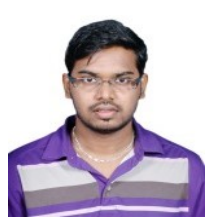

Rakesh R, MTech Student, Department of Civil Engineering, Global Academy of Technology, Bengaluru -560098 